\title{
Kadınların Özel Hallerinde Mescide Girmesini İlgilendiren Rivâyetlerin Tahlili ve Değerlendirilmesi
}

\begin{tabular}{|c|}
\hline $\begin{array}{c}\text { Şule Soyal Şenol* } \\
\text { Diyanet İşleri Başkanlığı } \\
\text { Bartın Müftülü̈̆̆̈̈ } \\
\text { orcid.org/0000-0002-9726-9924 }\end{array}$ \\
\hline$\ddot{O} z$ \\
\hline $\begin{array}{l}\text { Kadınların özel hallerinde mescide girip giremeyeceği İslâm'ın ilk dönemlerinden beri } \\
\text { tartışılan konulardan olmuştur. Günümüzde kadınların toplumsal hayatın her alanına tekrar } \\
\text { girmesiyle beraber, bu konu yeniden gündemi meşgul etmeye başlamıştır. Kadınların camiye } \\
\text { girmesi, Kur'an eğitimi almak veya vermek, çeşitli kültürel etkinliklere katılmak, toplantı yapmak, } \\
\text { dinlenmek, turistik ziyaret yapmak gibi sebeplerle zorunlu hale gelmiştir. Bu konu İslam } \\
\text { hukukçuları tarafından da ele alınmakta ve çözüm aranmaktadır. Konunun açılı̆̆a kavuşması } \\
\text { kadınlar ve bilim dünyasına adına zorunlu hale gelmiştir. Konuyla ilgili klasik fikhî mezheplerin } \\
\text { farklı görüşler ortaya koydukları görülmektedir. "Hayızlı kadın kesinlikle mescide giremez" } \\
\text { diyenler olduğu gibi "girmesi caizdir" de denilmiştir. Yine "mescidi kirletme endişesi yoksa sadece } \\
\text { geçmesi caizdir" denildiği gibi günümüzde " kirletme endişesi yoksa tören izlemek, ziyaret etmek } \\
\text { gibi durumlarda girebileceği" söylenmiştir. Her bir grup kendi görüşlerini destekleyen deliller ileri } \\
\text { sürmüşlerdir. Bu noktadan yola çıkarak ilgili fetvalara delil olarak gösterilen rivâyetler derlenmiş } \\
\text { ve senet kriterleri içerisinde incelenmiştir. Araştırma neticesinde elde edilen veriler, sonuç } \\
\text { bölümde belirtilmistir }\end{array}$ \\
\hline
\end{tabular}

Anahtar Kelimeler: Hayız, Âdet, Lohusa, Mescid, Cami, Hadis

\section{The Analysis and Assessment of Hadith Narrations related to the Entry into the Masjid During the Women's Special Circumstances}

\section{Abstract}

Whether women are allowed to enter the mosque during their menstruation has been one of the topics discussed since the early days of Islam. Today, as women are entering into every aspect of social life again, this issue has re-emerged on the agenda. It has become unavoidable for women not to enter the mosque due to reasons such as receiving or teaching Quranic education, participating in various cultural activities, having meetings, resting, and touristic visits. This issue has also been addressed by Islamic scholars and the solution is being sought. It has become mandatory for women and the world of science to clarify this matter. It is observed that denominations of the classical Islamic jurisprudence have different opinions. While there are those who say that "by no means menstruating woman can enter the mosque", there are also those who say "it is permissible to enter". Nevertheless, while it has been traditionally said that "it is permissible to just pass through if there is no concern for contamination of the mosque", nowadays it is being said that "if there is no concern for contamination it is permissible during occasions such as watching ceremonies and visiting. "Each group has put forward their evidences to support their own views. From this perspective, all narrations that were presented as evidence for these respective fatwas (Islamic rulings) were 
examined and analyzed within the chain criteria. The data obtained from this study are shared in the Results section.

Keywords: Menstruation, Period (Special circumstances), Puerpera, Masjid, Mosque, Hadith .

\section{Giriş}

İslam dininde kulluk ve insan olma bakımından kadın ve erkeğin eşit olduğu tartışmasız bir gerçektir. ${ }^{1}$ Bununla birlikte bazı dinî ve hukukî konularda her iki cins arasında farklı uygulamalar da görülmektedir. Örnel olarak Cuma namazı bu konuda örnek olarak zikredebilir. ${ }^{2}$ Cinsiyet farklılığı ve bunun sonuçları, hayatın devamı ve düzeni için zaruridir. Erkek ve kadında cinsiyet farkları hem bedenî hem de ruhî yönden esaslı ve değişmez özelliklerdir. ${ }^{3}$ Bu durum İslâm açısından her iki cinsin aynı insanî değerleri taşımasını engellemez. Nitekim Kur'ân-1 Kerim'de ${ }^{4}$ insanlar arasında en büyük değer farkının, cinsiyet ayrılığı gözetmeksizin iman, amel, bilgi, takvâ gibi erdemlerdeki derecelerine bağlı olduğuna işaret edilmiştir. Bu yönden kadın ve erkek olarak her iki cinsin de Allah katında aynı değeri taşıdığı özellikle vurgulanmıştır. ${ }^{5}$ İslâm öncesi dönemde Arapların kadını aşağılayan anlayışları da şiddetle reddedilmiştir. ${ }^{6}$

Kadınların ve erkeklerin ibâdetlerini camide yerine getirmesi meşrudur. Hz. Peygamber kadınları mescide gitmeleri konusunda teşvik etmiş hatta engel olmak isteyenleri de uyarmıştır. ${ }^{7}$ Kadınların özel hallerinde mescide girmesini yasaklayan rivâyetlerin bulunması sebebiyle mezheplerin çoğu, kadınların mescidlere girmesini caiz görmemiştir. ${ }^{8}$ Ancak bu yasağın temel illeti konusunda aralarında görüş birliği yoktur. Mevcut ihtilaflar ve hükümler bu illete dönük görüşlere göre şekil almaktadır. ${ }^{9}$

Günümüzde kadınların camilere, eğitim ve sosyal-kültürel amaçlarla girmesi zorunlu hale gelmiştir. Mesela Diyanet İşleri Başkanlığı'na bağlı kadın Kur'ân Kursu öğreticilerinin ve vaizlerin çalışma sahası çoğunlukla camilerdir. Yine Kur'ân eğitimi verme ve alma, kültürel etkinlikler ve toplantılar yapma, dinlenme, turistik ziyaret, mimari inceleme gibi birçok etkinlik, camilerde veya cami müştemilatında yapılmaktadır. Saydığımız bu ihtiyaçlar sebebiyle kadınların camilere girme zorunluluğu daha da artmıştır. Ne var ki toplumumuzda, hayızlı kadınların camiye

\footnotetext{
${ }^{1}$ el-Âl-i İmran, 3/195; en-Nisâ, 4/1; et-Tevbe, 9/71; en-Nahl, 16/97; el-Hucurat, 49/13.

2 Şahin Osman, "Cuma Namazı Mükellefiyeti”, İslam Hukuku Araştırmaları Dergisi, S: 25 (2015), s.419-451.

${ }^{3}$ Hökelekli Hayati, "Cinsiyet", TDV İslâm Ansiklopedisi, C:VIII, S: 21-24, Türkiye Diyanet Vakfı Yayınları, İstanbul, 1993.

${ }^{4}$ el-En'âm 6 / 132; ez-Zümer 39 / 9; el-Mücâdile 58 / 11.

${ }^{5}$ en-Nisâ 4 / 124; en-Nahl 16 / 97; el-Ahzâb 33 / 35.

${ }^{6}$ en-Nahl 16 / 58-59; ez-Zuhruf 43 / 17; et-Tekvîr 81 / 8-9.

${ }^{7}$ Müslim, Ebü'l-Hüseyn Müslim b. el-Haccâc b. Müslim el-Kuşeyrî, Sahîhu Müslim, (Riyâd: Beytu Efkâri Düveliyye 1998), Salât 135.

${ }^{8}$ el-Mevsilî, Abdullah b. Mahmûd b. Mevdûd el-Mevsılî, el-ïhtiyâr, (Beyrût: Dâru'l-Kütübü'l-İlmiyye 2015), c.1, s.13; el-Abderî, Muhammed b. Yûsuf b. Ebî'l-Kâsım b. Yûsuf, et-Tâc ve'l-İklîl lî Muhtasari Halîl, (Beyrût: Dâru'l-Kütübü'l-İlmiyye 2002), c.1, s.462; eş-Şirbînî, Muhammed b. Muhammed el-Hatîb eş-Şirbînî, Muğni'l-Muhtâc ilâ Ma'rifeti Meânielfâzi'l-Minhâc, ( Beyrût: Dâru'l-Kütübü'l-İlmiyye 2000), c.1, s.211.

9 Yüksek Ali, "İslam Fıkhına Göre Kadınların Âdet Ve Lohusalık Günlerinde Mescitlere Giriş Sorunu”, Ondokuz İlahiyat Fakültesi Dergisi, S: 41 (2016), s. 77-97.
} 
girmesi kesinlikle haram olduğu görüşü yaygındır. Hayızlı kadınların mescide girmesine cevaz veren âlimler ${ }^{10}$ olduğu bilgisinin gündeme gelmesi kadınlar tarafında şaşkınlıkla karşılanmıştır. İl ve ilçe müftülüklerine şahsen veya telefonla yöneltilen sorular arasında hayızlı kadınların camilere girmesinin hükmü de yer almaktadır. ${ }^{11}$

Bu çalışmamızda verilen hükümlere mesned teşkil eden rivâyetler, senet tenkidi açısından ele alınacaktır. Böylece konuyla ilgili görüş belirten tarafların delilleri irdelenerek kadınların bu ihtiyacına çözüm üretmek hedeflenmektedir.

\section{Kavramsal Çerçeve}

Konunun daha iyi anlaşılması için ilgili bazı kavramların açıklanması yerinde olacaktır:

\subsection{Mescid}

Mescid kavram1, Arapça'da (سجد/secede) fiilinden türemiş ism-i mekân kalıbında bir isimdir. Sücûd (secde etmek) aynı kökten mastar olup "alnı yere koymak" demektir. Buna göre mescid, "secde edilen yer, secde yeri" gibi anlamlar taşır. ${ }^{12}$ İsfehânî ise sücûd kelimesine, tezellül anlamı yüklemiş ve "Allah’a karşı, boyun eğmek ve O'na kulluk etmek" anlamlarına geldiğini söylemiştir. ${ }^{13}$

\subsection{Câmi}

Câmi, köken itibariyle (جمع/cemea) fiilinden türemiş "toplayan, bir araya getiren" anlamında bir ism-i fâildir. Câmi kavramı mescidden ayrı bir kavram değil, onunla ilişkili bir kavramdır. Câmi, mescidin bir sıfatı konumundadır. Buna göre, mescidin bir sıfatı olarak câminin (el-mescidu'l-câmi') "toplayan, bir araya getiren mescid" anlamına geldiği söylenebilir. İslam'ın hızla yayılması, şehirlerin hızlı bir şekilde büyümesine neden olmuş, bunun bir sonucu olarak da belli merkezlerde pek çok mescid inşâ edilmiştir. Hal böyle olunca, Cuma ve bayram namazlarının kılındığı mescidleri diğerlerinden ayrı tutmak maksadıyla "câmi" sıfatı kullanılmaya başlanmıştır. ${ }^{14}$

Kur'ân-1 Kerîm, hadisler ve ilk İslâm kaynaklarında cami kelimesinin yerine mescid kelimesinin kullanıldığı görülmektedir. ${ }^{15}$ Biz bu çalışmamızda mescid kelimesini kullanmayı tercih ettik.

\footnotetext{
10 İbn Hazm, Alî b. Ahmed b. Saîd b. Hazm, el-Muhallâ bi'l-Âsâr, (Beyrût: Dâru'l-Kütübü'l-İlmiyye 2015), c.1, s.400.

${ }^{11}$ Diyanet İşleri Başkanlığı, Aile İle İlgili Sıkça Sorulan Sorular, (Ankara: Diyanet İşleri Başkanlığı Yayınları 2015), s.177; https://kurul.diyanet.gov.tr/Cevap-Ara/108/adetli-ve-lohusa-kadin-camiye-girebilir-mi(09.11.2018).

12 İbn Manzûr, Ebu'l-Fadl Cemalu'd-din Muhammed b. el-'İzz b. el-Mukerrem el-Ensârî, Lisânü'l-arab, (Beyrût: Dâru Sâdir 2003).

13 el-İsfehânî Rağıb, el-Müfredât fi garîbi'l-Kur'ân, Çev: Abdülbaki Güneş, Mehmet Yolcu, (İstanbul: Çıra Yayınları 2012), s.239.

${ }^{14}$ Gündoğdu Yusuf Bahri, "Mescidlerin Ayrlmaz Bir Unsuru Olarak Ĕ̆gitim", The Journal of Academic Social Science Studies, S:45 (2016), s.313-325.

15 Önkal Ahmet - Bozkurt Nebi, "Cami ( Din̂̂ ve Sosyokültürel Tarihi )", TDV İslâm Ansiklopedisi, C:VII, S: 46-56, Türkiye Diyanet Vakfı Yayınları, İstanbul, 1993.
} 


\subsection{Mescidin Fonksiyonu}

Şüphesiz mabetlerin temel kuruluş amaçları ve en başta gelen ortak özellikleri ibadettir. Ancak başta sinagog, kilise ve cami olmak üzere büyük mabetlere bakıldığında onların birer ibadetgâh olmalarının yanında eğitim-öğretim fonksiyonları olan birer eğitsel kurum oldukları da görülmektedir. Mescidin tarihçesine göz atıldığında Asr-1 Saâdet'te kurulan ilk örneklerden başlamak üzere onun sadece bir ibadethane değil; aynı zamanda fonksiyonel bir eğitim-öğretim kurumu olduğu, zamanla burada dini olan ve olmayan birçok ilmin okutulduğu ve bu bağlamda cami eğitimine has bir terminolojinin doğduğu görülmektedir. ${ }^{16}$

Medine'de Peygamber Efendimiz (s.a.s.)'in kurduğu ilk mescid (Mescidü'nNebi) ibadet merkezi, ilim merkezi, eğitim ve öğretim merkezi olmanın yanında, toplumla ilgili her türlü çalışmanın ve faaliyetin merkezi olma özelliğini de taşımakta idi. ${ }^{17}$ Bütün bu özellikler mescide sahâbe hanımların da gelip gitmesine imkân vermekteydi.

Peygamber Efendimiz (s.a.s.)'in bizim için son derece önemli ve dikkat çekici olan bir tavrı, mescide gelmek isteyen kadınlara mani olmak isteyen erkek sahâbîleri uyarması ve onları böyle bir davranıştan menetmesidir: "Hanımlar gece (akşam, yatsı ve sabah) namazlarına katılmak için sizden izin istediklerinde izin veriniz."18 buyurmuştur. Kadınların mescide devam etmelerine ve namazları cemaaatle kılmalarına önem veren Hz. Peygamber, yine erkek ashâbına hitâben: "Allah'ın hanım kullarını, Allah'ın mescidlerinden men etmeyiniz!"19 buyurarak onların mescide devam etmelerinin önündeki muhtemel engelleri kaldırmıştır.

Kadınlar, Hz. Peygamber Efendimiz zamanında beş vakit namaz, Cuma namazı, bayram namazı ve cenâze namazlarına katılmışlardır. Hz. Peygamber, kadınların mescide rahat gidip gelmelerini sağlamak için bazı tedbirler almıştır. Bu tedbirlerin başında, mescidin bir kapısının kadınlara tahsis edilmesi gelmektedir. ${ }^{20}$

Hz. Peygamber, kadınlara yönelik nasihatleri ilk zamanlar mescidde vermiştir. ${ }^{21}$ Cuma namazına devam eden kadınların, Hz. Peygamber'den çok şeyler öğrendiklerini yine onlardan gelen haberlerden öğreniyoruz. Ümmü Hişâm bint Hârise şöyle demiştir: "Ben, Kâf sûresini Cuma namazlarında Hz. Peygamber'den öğrendim. Çünkü O, her Cuma günü minberde Kâf sûresini okurdu."22

\footnotetext{
${ }^{16}$ Yıldırım Kadri, "İslam Kültüründe Mescidin Eğitim Öğretim Fonksiyonu Üzerine Bir İnceleme", Diyanet İlmi Dergi, Diyanet İşleri Başkanlığı Dini Yayınlar Dairesi Başkanlığı, C: 44, S: 4 (2008), s. 7-28.

${ }^{17}$ Bozkurt Nebi - Küçükaşcı Mustafa Sabri, "Mescid-İ Nebevî̀, TDV İslâm Ansiklopedisi, C:XXIX, Türkiye Diyanet Vakfı Yayınları, İstanbul 2004, s. 289.

18 Buhârî, Ebû Abdullâh Muhammed b. İsmâîl b. İbrâhîm el-Cưfî̀ el-Buhârî, el-Câmiu's-Sahîh, (Riyâd: Beytu'l-Efkâr 1998), Ezân 163, Salât 162.

${ }^{19}$ Ahmed b. Hanbel, Ebû Abdillâh Ahmed b. Muhammed b. Hanbel eş-Şeybânî el-Mervezî, Müsned, II, 76; Buhârî, Cum'a 13, Nikâh 116.

${ }^{20}$ Ebû Dâvud, Süleymân b. Eşâsî el-Ezdî es-Sicistânî, Kitabü'-Sünen, haz. Muhammed Avvâme, (Beyrût: Müessesetü'r-Rayyân 2004), Salât 54.

${ }^{21}$ Ebû Dâvûd, Nikâh 49.

${ }^{22}$ Ahmed b. Hanbel, Müsned, VI, 436; Müslim, Cuma 51.
} 
Bayram namazlarına ve cenâze namazlarına katılanlar da hem namazlarını cemaatle kılar hem de bir şeyler öğrenirlerdi. Hatta Hz. Peygamber, şer'an özürlü olan kadınların da bayram namazlarına katılmasını isterdi. ${ }^{23}$ Hanım sahâbilerden Ümmü Atiyye, Medîne Mescidi dışında açık alanda kılınan bayram namazında, âdet gören kadınların, arka kısımlarda yer aldıklarını ve cemaatle birlikte tekbir getirdiklerini de haber vermektedir. Hz. Peygamber, bayram namazlarında kadınlara ayrıca nasihat etmiş ve onlardan yoksul Müslümanlar için sadaka toplamıştır. ${ }^{24}$

Kadınlar, kendilerini ilgilendiren konularda Hz. Peygamber'e sorular sormuş ve bu konularda bilgi almışlardır. ${ }^{25} \mathrm{~Hz}$. Peygamber' in Medîne'de yaptırdığı mescidin arka tarafında kadınlara ayrılan bir bölüm bulunmaktaydı. Kadınlar namazlarını burada kılmışlar, Hz. Peygamber'in sohbetlerini de buradan dinlemişlerdir. Hz. Peygamber'in mihrabı ve minberi ile kadınlar bölümü arasındaki mesafenin uzak olması sebebi ile kadınlar, Hz. Peygamber'in sözlerini iyice dinleyemediklerinden şikâyet etmişler ve kendileri için ayrı bir zamanın tahsis edilmesini istemişlerdir. Ebû Saîd el-Hudrî’den gelen bir rivâyet şöyledir: "Kadınlar, "Ey Allah'ın elçisi (sözlerinizi dinleyip iyice anlamak için) erkeklerden bize meydan kalmıyor. Kendiliğinizden bize bir gün ayırını." dediler. Rasûlullah (s.a.v.) da onlara bir gün tayin etti. Kadınlar, o gün Hz. Peygamber'in huzuruna geldiler. O da kendilerine vaaz ve nasihat yaptı, yapmalarn gereken şeyleri emretti."26

\section{Hayızlı Halde Mescide Girmek İle İlgili Rivâyetlerin Tahlili ve Değerlendirilmesi}

Hayızlı kadınların mescide girmesi konusu tartışılan konulardan olmuştur. Bu konuda farklı görüşler ileri sürülmüştür: "Hayızlı kadın kesinlikle mescide giremez" diyenler ${ }^{27}$ olduğu gibi "girmesi caizdir" 28 de denilmiştir. Yine "mescidi kirletme endişesi yoksa sadece geçmesi caizdir" denildiği gibi günümüzde kirletme endişesi yoksa tören izlemek, ziyaret etmek gibi durumlarda girebileceğ ${ }^{29}{ }^{20 ̈ y l e n m i s ̧ t i r . ~}$

Bu konu ile ilgili rivâyetleri üç başlıkta sayabiliriz:

- Kadınların bayram namazına çıkış rivâyeti

- Hz. Peygamber'in Hz. Âişe'den seccadeyi getirmesini istediği rivâyet

- Hz. Peygamber'in sahâbilere evlerinin kapılarının yönünü değiştirmelerini emrettiği rivâyet

\footnotetext{
${ }^{23}$ Buhârî, Îdeyn 20; Ebû Dâvûd, Salât 247.

${ }^{24}$ Buhârî, Îdeyn 19.

${ }^{25}$ Buhârî, Hayz 9.

${ }^{26}$ Buhârî, İlim 36.

27 Şeyh Nizam, Fetâvâ-yı Hindiyye, (Beyrût: Dâru'l-Fikr 2009), c. 1, s. 92; el-Mevsılî, el-İhtiyâr, c.1, s.13; elAbderî, et-Tâc ve'l-İklîl, c.1, s.462; eş-Şirbînî, Muğni'l-Muhtâc, c.1, s.211.

28 İbn Hazm, el-Muhallâ, c.1, s.400, İbn Rüşd, Ebû'l-Velîd Muhammed bin Ạ̣med bin Muhammed, Bidâyetü'l-Müctehîd ve Nihâyetü'l- Muktesîd, (Beyrût: Dâru İbn Hazm 1995), I, 100.

${ }^{29}$ Dalgın Nihat, Gündemdeki Tartışmalı Dini Meseleler, (İstanbul: Ensar Neşriyat 2014), s. 43.
} 


\subsection{Kadınların Bayram Namazına Çıkış Rivâyeti}

Hayızlı kadınların namaz yerinden ayrı durarak bayram namazlarının kılındığı sahada hâzır bulunmalarını anlatan hadisi Buhârî, ${ }^{30}$ Müslim, ${ }^{31}$ Nesâî, $^{32}$ Tirmizî,, 33 Ebû Dâvud, ${ }^{34}$ İbn Mâce ${ }^{35}$ ve Dârimî ${ }^{36}$ rivâyet etmişlerdir.

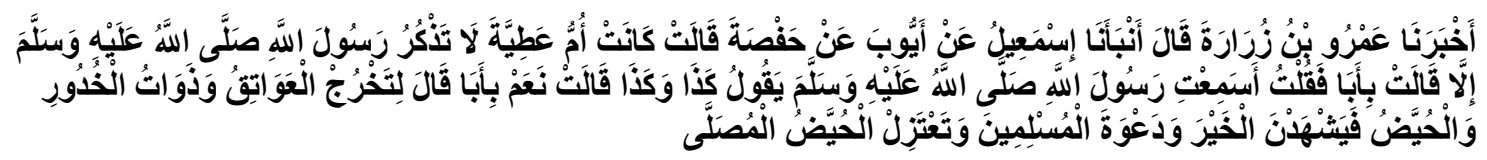

“Bize Amr b. Zürâre, İsmâîl'den, o da Eyyûb'tan, o da Hafsa'dan şöyle rivâyet etti: Ümmü Atiyye ile karşılaştım ve ona dedim ki: Peygamber (s.a.v)'den bizzat şöyle şöyle dediğini duydun mu? O da: Evet, dedi ve ( Hz. Peygamber) 'akıl baliğ olan ve olmayan genç kızlar bayram namazına ve Müslümanlarm davetine katılsınlar, hayızlılar ise musalladan uzak dursunlar' dedi." 37

Buhârî'nin, Hafsa'dan rivâyet ettiği bu hadisi, diğer kaynaklar Ümmü Atıyye'den rivâyet etmişlerdir. Bu isnâdı, rivâyeti eserlerinde nakleden müelliflerle birlikte şema üzerinde şu şekilde göstermek mümkündür:

\footnotetext{
${ }^{30}$ Buhârî, Hayız 23; Iydeyn 18.

${ }^{31}$ Müslim, Iydeyn 1.

${ }^{32}$ Nesâî, Ebû Abdirrahmân Ahmed b. Şuayb b. Alî en-Nesâî, Sünenü'l-Kübrâ, haz. Abdullah bin Abdu'lMuhsin, (Beyrût: Müessesetü'r-Risâle 2001), Salâtü'l-Iydeyn 3.

33 Tirmizî, Muhammed b. Îsâ, Câmiu'l-Kebîr, haz. Beşşâr Avvâme, (Beyrût: Dâru'l- Ğarabi'l-İslamî 1996), Iydeyn 388 .

${ }^{34}$ Ebû Dâvûd, Salât 238

35 İbn Mâce, Ebû Abdillâh Muhammed b. Yezîd Mâce el-Kazvînî, Sünen-i İbn Mâce, (Riyâd: Mektebetü'lMaârif tarih yok), Salât ikame 165.

${ }^{36}$ Dârimî, Ebû Abdullâh bin Abdu'r-Rahmân b. Fadl bin Behram, Sünenü'd-Dârimî, haz. Hasan Selim Esed, (Riyad: Dâru'l-Muğanni 2000), Salât 224.

37 Nesâî, Ebû Abdirrahmân Ahmed b. Şuayb b. Alî en-Nesâî, Sünenü'l-Kübrâ, haz. Abdullah bin Abdu'lMuhsin, (Beyrût: Müessesetü'r-Risâle 2001), Salâtü'l-Iydeyn 3.
} 


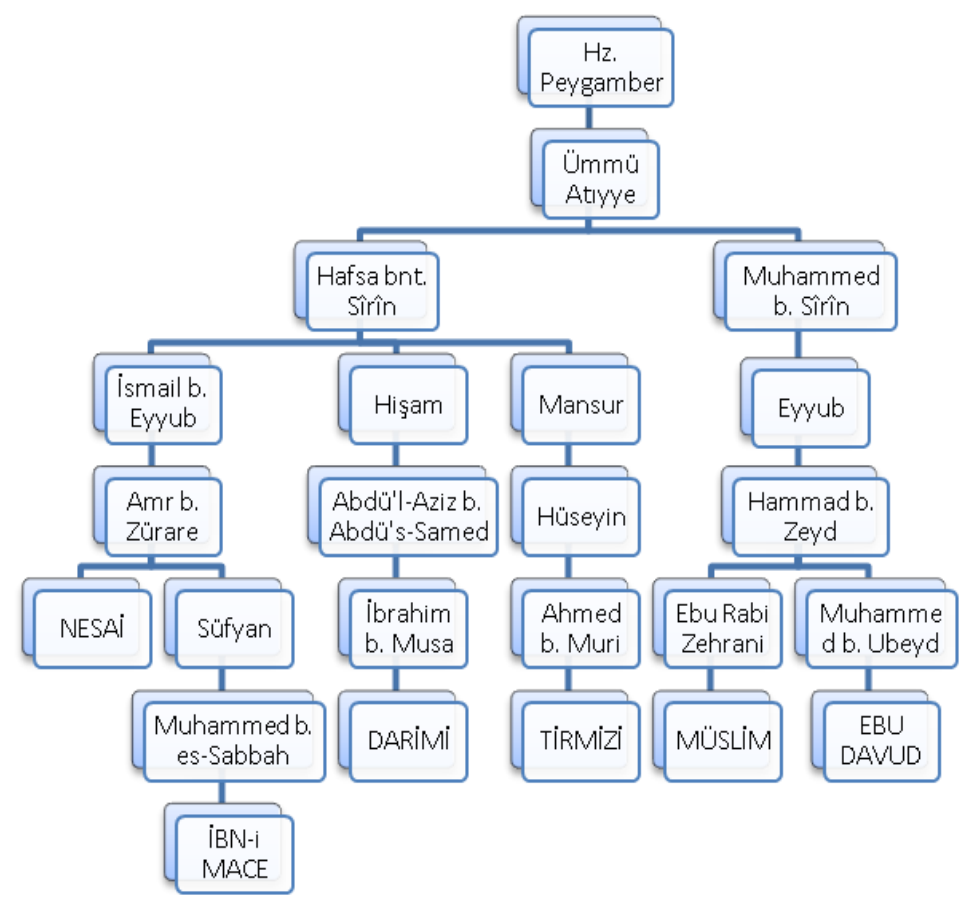

Rivâyeti Ümmü Atıyye'den, Hafsa bnt. Sîrîn ve Muhammed b. Sîrîn nakletmiştir. Hafsa bnt. Sîrîn 'den on râvi, Muhammed b. Sîrîn'den ise dört râvi nakletmiştir.

İsnâd şemasındaki bazı râvilerin güvenirlilik durumları şöyledir:

\subsubsection{Râvilerin Değerlendirilmesi}

Nesâî $\Rightarrow$ Amr b. Zürâre $\Rightarrow$ İsmâîl b. Eyyûb $\Rightarrow$ Hafsa binti Sîrîn $\Rightarrow$ Ümmü Atıye Hz. Peygamber

\section{Ümmü Atıyye:}

Ümmü Atıyye Nüseybe bint el-Hâris el-Ensâriyye, hadis râvilerinden Dubâa bint Hâris'in kardeşi olan kadın sahâbîdir. ${ }^{38} \mathrm{~Hz}$ Peygamber'den ve Ömer b. Hattâb'tan rivâyette bulunmuştur. Hicri 70 yılına kadar yaşadığı zikredilen Ümmü Atıyye, çok hadis rivâyet eden kadın sahâbîlerden olup Enes b. Mâlik, İbn Sîrîn, Hafsa bnt. Sîrîn, Abdülmelik b. Umeyr, âzatlısı Ümmü Şerâhîl, torunu İsmâîl b. Abdurrahmân b. Atıyye ve Ali b. Akmer kendisinden hadis rivâyetinde bulunmuştur. ${ }^{39}$ Ümmü Atıyye'nin Kütüb-i Sitte ile Ahmed b. Hanbel'in el-Müsned'indeki hadislerinin sayısı tekrarlarıly birlikte 100 'ü aşmaktadır.

\footnotetext{
38 İbn Hibban, Ebû Hâtim Muhammed bin Hibbân bin Ahmed el-Büstî, Kitâbü's- Sikât, (Hindistan: Müessesetü Kütübi's-Sekafiyye tarih yok), III, 423; İbn Hâcer el-Askalâni, Ebû'l-Fazl Şihâbüddîn Ahmed bin Alî bin Muhammed, Et-Takrîbü't-Tehzîb, (Riyâd: Dâru'l-Âsîme tarih yok.), s. 1374.

${ }^{39}$ Mizzî, Ebü'l-Haccâc Cemâlüddîn Yûsuf b. Abdirrahmân b. Yûsuf el-Mizzî, Tehzîbü'l-Kemâl, (Beyrût: Müessesetü'l- Risâle 2010), VIII, 581.
} 


\section{Hafsa binti Sîrîn:}

Ümmü'l-Hüzeyl el-Ensârî, Enes b. Mâlik, Rabi b. Ziyâd ve Ebû Âliye'den rivâyetlerde bulunmuştur. Ondan kardeşi Muhammed, Katâde, Eyyûb gibi kimseler rivâyet almıştır. Iclî, "tabiundan" olup "sika" olduğunu; Ahmed b Ebî Meryem de "sika ve hüccet" olduğunu söylemiştir. İbn Hibban, Sikat'ta onu zikretmiştir. ${ }^{40}$ İbn Hacer, "üçüncü tabakadan olup sikadır" demiştir. Hicri yüz bir senesinde vefat etmiştir. ${ }^{41}$

\section{İsmâîl b. Eyyûb:}

Eyyûb b. Ebî Temîme Keysânî es-Sahtiyânî, Kütüb-i Sitte râvilerinden olup pek çok kimseden rivâyet almıştır. Yaklaşık sekiz yüz kadar rivâyeti olduğunu Buhârî nakletmiş, Bişr b. Âdem ise bin rivâyeti vardır demiştir. ${ }^{42}$ İbn Sa'd, "hadiste sika ve sebt, ilimlerin çoğuna hâkim, hüccet ve adildir" derken Nesâî de, "sika ve sebt" demiştir. ${ }^{43}$ İbn Hacer, "sika, sebt, hüccet ve fakihlerin ileri gelenlerinden" olduğunu söylemiştir. Hicri 131 yılında vefat etmiştir. ${ }^{4}$

\section{Amr b Zürâre:}

Amr b Zürâre b. Vâkid el-Kilâbî, Ebû Muhammed b. Ebî Amr en-Neysâbûrî hafızdır. Ebû Bekr b. Ayyâş̧, Muâz b. Muâz, Süfyân b. Uyeyne gibi kimselerden rivâyetleri vardır. Buhârî, Müslim, Nesâî gibi pek çok kimse ondan rivâyette bulunmuştur. ${ }^{45}$ Nesâî, "sika"; Ebû Amr el-Müstemli "sikatü's-sikat (çok güvenilir)" demişlerdir. İbn Hibban Sikat' 1 nda zikretmiştir. Hicri 238 senesinde vefat etmiştir. ${ }^{46}$

\subsubsection{Senedin Değerlendirilmesi}

Nesâî'nin Sünen'inde yer alan rivâyet, beş tabaka ile Hz. Peygamber'e ulaşmıştır. Senedinde sika râvilerin bulunması sebebiyle sahihtir.

\subsubsection{Râvilerin Değerlendirilmesi}

Müslim $\Rightarrow$ Ebû Rabi' Zehrânî $\Rightarrow$ Hammâd b. Zeyd $\Rightarrow$ Eyyûb $\Rightarrow$ Muhammed b. Sîrîn $\Rightarrow$ Ümmü Atıye $\Rightarrow$ Hz. Peygamber

\section{Muhammed b. Sîrîn:}

Muhammed b. Sîrîn el-Ensarî; Enes b. Mâlik, Hz Âişe, Hasan b Ebî Tâlib, Semüre b. Cündeb gibi kimselerden rivâyette bulunmuştur. Ebû Tâlib, İbn Maîn, İbn Sa'd ve Iclî "sika" olduğunu söylemiştir. ${ }^{47}$ İbn Hacer "sika, abid" olduğunu söylerken

\footnotetext{
${ }^{40}$ Mîzzî, Tehzîbü'l-Kemal, VIII, 526; İbn Hacer, Tehzîbü't-Tehzîb, VII, 657.

${ }^{41}$ İbn Hacer, Et-Takrîb, s. 1349.

${ }^{42}$ Mîzzî, Tehzîbü'l-Kemal, I, 314; İbn Hacer, Tehzîbü't-Tehzîb, I, 374.

${ }^{43}$ Buhârî, Et-Târihu'l-Kebîr, I, 381; Mîzzî, Tehzîbü'l-Kemal, I, 315; İbn Hacer, Tehzîbü't-Tehzîb, I, 375.

${ }^{44}$ İbn Hacer, Et-Takrîb, s. 158; İbn Hacer, Tehzîbü't-Tehzîb, I, 375.

${ }^{45}$ Mîzzî, Tehzîbü'l-Kemal, V, 414; İbn Hacer, Tehzîbü't-Tehzîb, V, 31.

${ }^{46}$ Mîzzî, Tehzîbü'1-Kemal, V, 415; İbn Hacer, Tehzîbü't-Tehzîb, V, 32.

${ }^{47}$ Mîzzî, Tehzîbü'l-Kemal, VI, 340-34; İbn Hacer, Tehzîbü't-Tehzîb, V, 627.
} 
"mana ile rivâyette bulunmadı" kaydını düşmüştür. Hicri yüz on senesinde vefat etmiştir. ${ }^{48}$

Eyyûb: Eyyûb es- Sahtiyanî: ( İsmâîl b. Eyyûb: Yukarıda hakkında bilgi verilmiştir.)

\section{Hammâd:}

Hammâd b. Zeyd b. Dirhem el-Ezdî; Ebû İsmâîl el-Basrî, Amr b. Dinâr, Hişâm b. Urve, Ubeydullâh b. Ömer gibi pek çok kişiden rivâyet almıştır. İbn Mübârek, Kattân, Sevrî gibi kimselerde ondan rivâyette bulunmuştur. ${ }^{49}$ İbn Hacer "sika, sebt ve fakih" demiştir. Amr b. Ali, Abdurrahmân b. Mehdî'den rivâyetle hadis âlimlerinin önde gelen dört isminden biri olduğunu söylemiştir. ${ }^{50}$ İbn Hibbân, Basra'da ondan daha fakih kimseyi görmediğini söylemiştir. ${ }^{51}$ İbn Sa'd, İbn Şeybe'nin onun için sika dediğini nakletmiştir..$^{52}$ Hicri yüz yetmiş dokuz senesinde vefat etmiştir. ${ }^{53}$

\section{Ebû Rabi’ Zehrânî:}

Süleymân b Dâvûd el-Atekiyyü; Abdullah b. Mübârek, Süfyân b. Uyeyne gibi pek çok kişiden rivâyet almıştır. Buhârî, Müslim, Ebû Dâvud çok kimseler ondan rivâyette bulunmuştur. ${ }^{54}$ İbn Hacer "sika" demiştir. ${ }^{55}$ Yahyâ b. Maîn, Ebû Zür'a, Ebû Hâtim ve Nesâî "sika" olduğunu söylerken, Yahyâ b. Maîn "sadûk" olduğunu da eklemiştir. ${ }^{56}$ Hicri iki yüz otuz dört senesinde vefat etmiştir. ${ }^{57}$

\subsubsection{Senedin Değerlendirilmesi}

Müslim'in Sahih'inde yer alan bu rivâyetin senedinde cerh edilen bir râvinin bulunmaması münasebetiyle, rivâyet sahihtir.

\subsubsection{Râvilerin Değerlendirilmesi}

Ebû Dâvûd $\Rightarrow$ Muhammed b. Ubeyd $\Rightarrow$ Hammâd b. Zeyd $\Rightarrow$ Eyyûb $\Rightarrow$ Muhammed b. Sîrîn $\Rightarrow$ Ümmü Atıye $\rightarrow$ Hz. Peygamber

\section{Muhammed b. Ubeyd:}

Abdü'l-Azîz b. Muhammed b. Ubeyd b. Ebî Ubeyd ed-Derâverdî. ${ }^{58}$ Yahyâ b. Maîn "bir sakınca yoktur" ve "hüccet" demiştir. Ebû Zür'a "hafızası kötü, kötü hafızadan dolayı hata yapabilir" demiştir. Nesâî "kuvvetli değildir" ve "bir sakıncası

\footnotetext{
${ }^{48}$ Mîzzî, Tehzîbü'l-Kemal, VI, 342; İbn Hacer, Et-Takrîb, s. 853.

${ }^{49}$ Mîzzî, Tehzîbü'l-Kemal, II, 274; İbn Hacer, Tehzîbü't-Tehzîb, VI, 195.

${ }^{50}$ Mîzzî, Tehzîbü'l-Kemâl, II, 274.

51 İbn Hacer, Tehzîbü't-Tehzîb, VI, 196.

52 İbn Hacer, Tehzîbü't-Tehzîb, VI, 196.

53 İbn Hacer, Et-Takrîb, s. 268.

${ }^{54}$ Mizzî, Tehzîbü'l-Kemâl, III, 277.

55 İbn Hacer, Et-Takrîb, s. 407.

${ }^{56}$ Mizzî, Tehzîbü'l-Kemâl, III, 278.

${ }^{57}$ Mizzî, Tehzîbü'l-Kemâl, III, 278; İbn Hacer, Et-Takrîb, s. 407.

${ }^{58}$ Mizzî, Tehzîbü'l-Kemâl, IV, 527.
} 
yoktur, Ubeydullâh b. Ömer'den hadisi münkerdir (hadisi reddedilmiştir)" açılamasını yapmıştır. ${ }^{59}$

\subsubsection{Senedin Değerlendirilmesi}

Müslim'in eserinde yer alan senet zincirindeki râvilere ek olarak ilgili rivâyette Muhammed b. Ubeyd bulunmaktadır. Muhammed b. Ubeyd hafiza bozukluğu sebebiyle cerh edilmiştir. Senedinde yer alan râvinin zabt yönünden mükemmel olmaması fakat lafız ve mana yönünden diğer rivayetlerle desteklendiği için bu rivayeti, hasen olarak değerlendirmek gerekmektedir. ${ }^{60}$

İbn Hacer, rivâyet ile ilgili şu açıklamaları yapmıştır: Hz. Peygamberin "Yalnız hayızlı kadınlar namazgâhtan uzak dursunlar" emri, çoğunluk tarafından hayızlı kadının namazgâhlardan uzak durmasının müstehap olduğu şeklinde anlaşılmıştır. Çünkü namazgâhlar, câmi olmadığı için hayızlı kadınların buralara gitmesi yasaklanmamıştır. İbnü'l-Müneyyir şöyle demiştir: "Kadınların namazgâhlardan uzak durmalarındaki hikmet şu şekilde açıklanabilir: Kadınların namaz kılmadıkları halde namazgâhlarda bulunmaları, tavır olarak bir bakıma küçümseme anlamına gelir. Bundan dolayı hayızlı kadınların namazgâhlardan uzak durması müstehap olmuştur."61

Aynî şu nakillerde bulunmuştur: “Hayızlı kadın Allah'ı zikretmekten alıkonamaz." Hattâbî ise "Kadınların hayırlı yerlerde, ilim meclislerinde bulunmaları gerekir. Fakat hayızlı iken mescide giremezler." demiştir. Nevevî; “Âlimler kadınların bayram namazına çıkmalarına izin vermişler ama bugün bu durum fitneye yol açmaktadır." ${ }^{62}$ demiştir.

Netice olarak Hz. Peygamber, hayızlılar da dâhil tüm kadınları bayram namazlarına çağırmıştır. Yağmurlu zamanlarda bayram namazını mescidde kıldıkları da bize ulaşan bilgiler arasındadır. ${ }^{63}$ Eğer Hz. Peygamber hayızlı kadının mescide girmesinde bir sakınca görmüş olsaydı, yağmurlu günlerde mescidde toplanırlarken gerekli uyarıları yapardı.

\subsection{Hz. Âişe'den Seccadeyi Getirmesini İstediği Rivâyet}

Bu rivâyeti Müslim, Nesâî, Tirmîzî, Ebû Dâvud, İbn Mâce ve Dârimî rivâyet etmişlerdir. ${ }^{64}$

\footnotetext{
${ }^{59}$ Mizzî, Tehzîbü'l-Kemâl, IV, 529.

60; İ̉n Salâh, Osmân b. Abdi'r-Rahmân eş-Şehrezûrî, Ulûmu'l-Hadîs, (Beyrût: Dâru'l-Fikr 1986), s.30; elMübârekpûrî, Ebü'l-Ulâ Muhammed Abdurrahmân b. Abdirrahîm, Tuhfetü'l-Ahvezî bi Şerhi Câmii'tTirmizî, (Beyrût: Dâru'l-Fikr 2008), c.3, s.91.

${ }^{61}$ İbn Hacer, Fethu'l-Bâri, I, 504.

${ }^{62}$ Aynî, Ebû Muhammed (Ebü's-Senâ) Bedrüddîn Mahmûd b. Ahmed b. Mûsâ b. Ahmed el-Aynî, Umdetü'l-Kâri fi Şerhi Sahîhi'l-Buhârî, (Beyrût: Dâru'l- Kitâbi'l-İlmiyye 2005), III, 452.

63 Ebû Dâvûd, Salât 248-251.

${ }^{64}$ Dârimî, Tahâret 82; Müslim, Hayız 3; İbn Mâce, Tahâret 120; Tirmizî, Muhammed b. Îsâ, Câmiu'l-Kebîr, haz. Beşşâr Avvâme, (Beyrût: Dâru'l- Ğarabi'l-İslamî 1996) Tahâret 101; Nesâ̂, Tahâret 120; Ebû Dâvûd, Tahâret 102.
} 


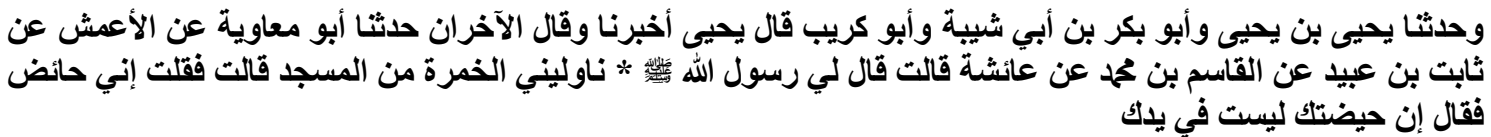

"Bize Yahyâ b. Yahyâ, Eb̂̂ Bekir b. Ebî Şeybe ve Ebû Kureyb, Yahyâ ve diğerlerinden,

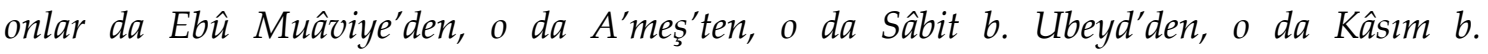
Muhammed'den şöyle rivâyet etmiştir: Âişe (r.anhâ) demiştir ki: "Rasûlullah (s.a.v.) bana, "Mescidden seccadeyi alıver." dedi. "Ben hayızlıyım" dedim. Bunun üzerine: "Senin hayzın elinde değildir" buyurdu." 65

$\mathrm{Bu}$ isnadı, rivâyeti eserlerinde nakleden müelliflerle birlikte şema üzerinde şu şekilde göstermek mümkündür:

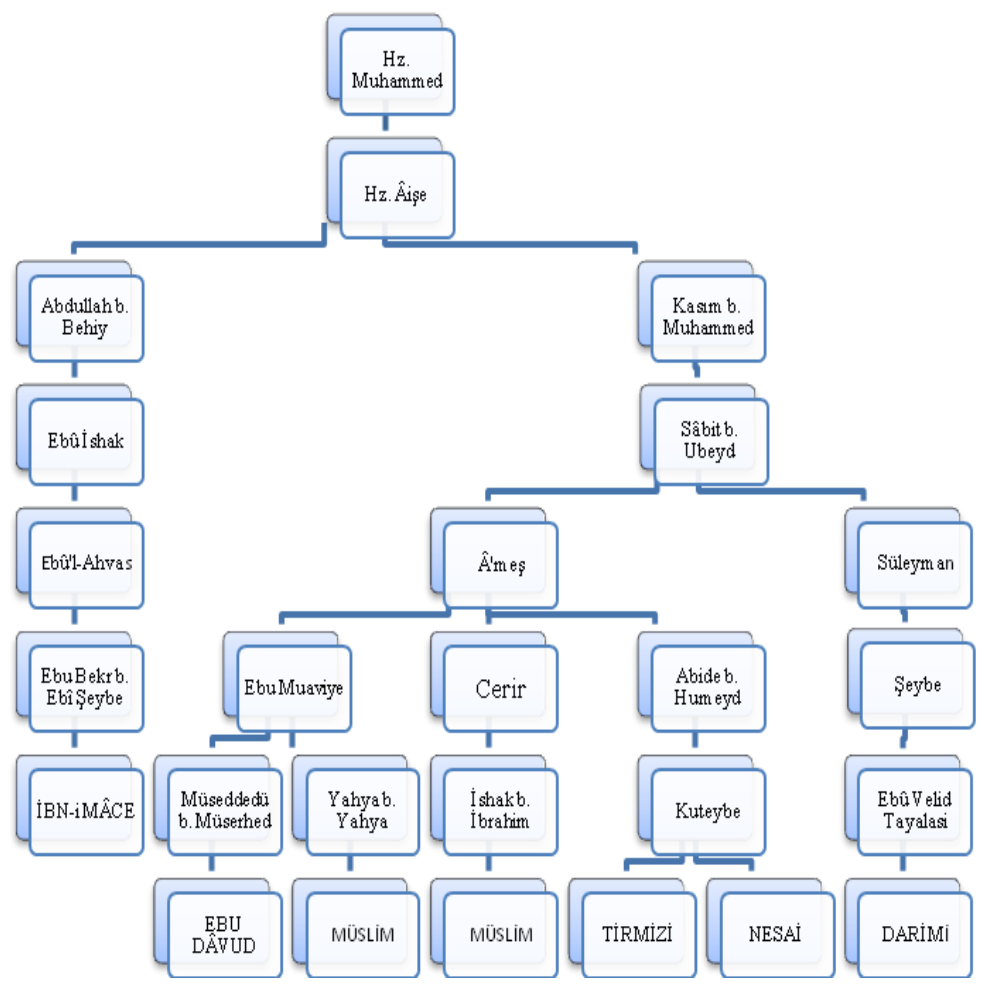

Hz. Âișe'den nakledilen hadis, Abdullah b. Behiy ve Kâsım b. Muhammed kanalıyla yayılmıştır. Abdullah b. Behiy kanalıyla ferd olarak gelen rivâyet, Kâsım b. Muhammed'den on dört râvi tarafından nakledilmiştir.

İsnâd şemasındaki bazı râvilerin güvenirlilik durumu şöyledir:

\subsubsection{Râvilerin değerlendirilmesi}

Kuteybe $\Rightarrow$ Abide b. Humeyd $\Rightarrow$ A'meş $\Rightarrow$ Sâbit b. Ubeyd $\Rightarrow$ Kâsım b. Muhammed $\Rightarrow$ Hz.Âişe $\Rightarrow$ Hz. Peygamber

\section{Kâsım b. Muhammed:}

Ebû Muhammed (Ebû Abdirrahmân) el-Kâsım b. Muhammed b. Ebî Bekr esSıddîk el-Kureşî et-Teymî el-Medenî, Medineli meşhur yedi tâbiîn fakihinden birisidir.

${ }^{65}$ Müslim, Hayız 3. 
Kendisi halası Hz Âişe, Zeyneb bnt. Cahş, Abdullah b. Abbas, Abdullah b. Ömer, Ebû Hüreyre, Muâviye b. Ebî Süfyân, Abdullah b. Amr b. Âs ve diğer bazı sahâbîlerden hadis rivâyet etti. Kendisinden hadis nakledenler arasında Yahyâ b. Saîd el-Ensârî, Alî b. Ebî Talhâ, Şa'bî, Nâfi, Sâlim b. Abdillâh b. Ömer, Ebû Bekir b. Hazm, Mâlik b. Dînâr, İbn Şihâb ez-Zührî, İbn Ebû Müleyke, Rebiatürre'y, Ubeydullâh b. Ömer b. Hafs, Ebü'z-Zinâd, Abdullâh İbn Avn, Eyyûb es-Sahtiyânî gibi isimler vardır. ${ }^{66}$ Kütüb-i Sitte râvilerinden olan Kâsım için Mus'ab ez-Zübeyrî "tâbiînin hayırlılarından" demiştir. İmam Mâlik onun "ümmetin fakihlerinden" olduğunu, Yahyâ b. Saîd elKettân da Medine'de Kâsım'dan daha faziletlisini görmediklerini söylemişlerdir. Hicri 106 yılında vefat etmiştir. ${ }^{67}$

\section{Sâbit b. Ubeyd:}

Sâbit b. Ubeyd el- Ensarî, Zeyd b. Sâbit'in kölesidir. İbn Ömer, Zeyd b. Sâbit, Muğîre b. Şube'den rivâyette bulunmuş, kendisinden de İbn Sîrîn, A'meş, Sevrî rivâyet almışlardır. ${ }^{68}$ Ahmed b. Hanbel, Yahyâ Saîd el-Kattân, Nesâî, ${ }^{69}$ İbn Hacer onu "sika" olarak değerlendirmişlerdir. ${ }^{70}$

\section{A'meș:}

Ebû Muhammed Süleymân b. Mihrân el-Kûfî, tâbiîn nesline mensup âlim olup hafızlığını tamamladıktan sonra öğrenimine kıraat ilmiyle başladı. Rivâyette bulunduğu meşhur muhaddisler arasında Saîd b. Cübeyr, Kays b. Ebî Hâzim, Ebû Vâil Şakîk b. Seleme ve Şa'bî zikredilebilir. Kendisinden de Ebû Hanîfe, Şu'be, Süfyân esSevrî, Süfyân b. Uyeyne, Abdullah b. Mübârek gibi hicrî II. yüzyılın meşhur âlimleri hadis rivâyet etmişlerdir. Hicri 148 yılında vefat etmiştir. ${ }^{71}$

\section{Ubeyde b. Humeyd:}

Ubeyde b. Humeyd b. Suheyb et-Temîmî, künyesi Ebû Abdurrahmân el-Kûfi, Hazzâî olarak bilinir. Rivâyette bulunduğu muhaddisler arasında el-Esved b. Kays, Ömer b. Râşid, Mansur b. Mu'temir, İsmâîl b. Ebî Hâlid bulunmaktadır. Kendisinden Ahmed b. Hanbel, Hasân b. Sabbâh, Ali b. Hucr gibi râviler rivâyet almıştır. ${ }^{72}$ Ahmed b. Hanbel ve Nesâî "leyse bihi be's (onda bir sakınca yok-sika)", Yahyâ b. Maîn ve İbn Sa'd "sika" demişlerdir. ${ }^{73}$ Hicri 190 yılında vefat etmiştir. ${ }^{74}$

\footnotetext{
${ }^{66}$ Mizzî, Tehzî̉ü̈'l-Kemâl, VI, 83; İbn Hacer, Tehzîbü't-Tehzîb, V, 309.

${ }^{67}$ Mizzî, Tehzîbü'l-Kemâl, VI, 84-85; İbn Hacer, Et-Takrîb, s. 794.

${ }_{68}$ İbn Hibban, Sikât, IV, 9; İbn Hacer, Tehzîbü't-Tehzîb, I, 493;.

${ }^{69}$ İbn Hacer, Tehzîbü't-Tehzîb, I, 493.

70 İbn Hacer, Et-Takrîb, s. 186.

${ }^{71}$ İbn Hacer, Et-Takrîb, s. 414.

72 İbn Hibbân, , Sikât, VII, 163; Mizzî, Tehzîbü'l-Kemâl, V, 85; İbn Hacer, Et-Takrîb, s. 654.

${ }^{73}$ Mizzî, Tehzî̉bü'l-Kemâl, V, 85.

${ }^{74}$ Mizzî, Tehzîbü'l-Kemâl, V, 86; İbn Hacer, Et-Takrîb, s. 654.
} 


\section{Kuteybe:}

Kuteybe b. Saîd b. Cemîl es-Sekafî, künyesi Ebû Recâ'dır. ${ }^{75}$ Leys b. Sa'd, İbn Lehîa, Ebû Avâne el-Vâsıtî, Mâlik b. Enes, Hammâd b. Zeyd ve Süfyân b. Uyeyne'den rivâyet almıştır. Yahyâ b. Maîn ile Ahmed b. Hanbel'den başka Abdullah b. Zübeyr elHumeydî, Nuaym b. Hammâd, Ali b. Medînî, Ebû Hayseme Züheyr b. Harb ve Ebû Bekir İbn Ebi Şeybe gibi âlimler de ondan hadis dinlemişlerdir. Rivâyetleri Kütüb-ü Sitte'de yer almaktadır. ${ }^{76}$ Ahmed b. Ebî Heysemi, Yahyâ b. Maîn'den, Ebû Hâtim ve Nesâî, Kuteybe için "sika" demişlerdir. Ayrıca İbn Hırâş ve Nesâî, Kuteybe'nin "sadûk" olduğunu da eklemiştir. ${ }^{77}$ Hicri 148 yılında vefat etmiştir. ${ }^{78}$

\subsubsection{Senetlerin Değerlendirilmesi}

Tirmizî ve Nesâî' nin eserlerine almış oldukları rivâyetlerin senetlerinde yer alan râvilerin durumları incelediğinde, cerh edilen bir râviye rastlanılmamıştır. Bu durumda ilgili rivâyetleri sahih olarak değerlendirmek gerekir.

\subsubsection{Râvilerin Değerlendirilmesi}

İbn Mâce $\Rightarrow$ Ebû Bekr b. Ebî Şeybe $\boldsymbol{\Rightarrow}$ Ebu'l-Ahves $\Rightarrow$ Ebû İshâk $\Rightarrow$ Abdullah elBehiy $\boldsymbol{\rightarrow}$ Hz.Âişe $\rightarrow$ Hz. Peygamber

İbn Mâce' de bulunan rivâyetin senet durumu da şöyledir:

\section{Behiy:}

Abdullah el-Behiy; Mus'ab b. Zübeyr'in kölesi olup Künyesi Ebû Muhammed'dir. ${ }^{79}$ Abdullah b. Ömer b. Hattâb, Abdullah b. Zübeyr, Ebû Saîd el-Hudrî, Urve b. Zübeyr'den rivâyetleri vardır. ${ }^{80}$ İbn Hacer, "sika" demiştir. ${ }^{81}$ İbn Hibban Sikat'ta zikretmiş, Buhârî Edeb'de ondan rivâyette bulunmuştur. ${ }^{82}$

\section{Ebû İshâk:}

Amr b. Abdillah b. Ubeyd, künyesi Ebû İshâk es-Sebîî' olup tabiundandir. ${ }^{83}$ Rivâyette bulunduğu muhaddisler arasında Erkâm b. Şurahbil, Heyseme b. Abdirrahmân, Alî b. Ebî Tâlib bulunmaktadır. Kendisinden Mansur b. Abdirrahmân, A'meş, Sevrî gibi pek çok kişi rivâyette bulunmuştur. ${ }^{84}$ Yahyâ b. Maîn, Ebû Hâtim ve Nesâ̂i "sika" demişlerdir. ${ }^{85}$ Hicri 127 yılında vefat etmiştir. ${ }^{86}$

\footnotetext{
75 İbn Hacer, Et-Takrîb, s. 799.

76̇ibn Hibbân, Sikât, IX, 20; Mizzî, Tehzîbü'l-Kemâl, VI, 104; İbn Hacer, Tehzîbü't-Tehzîb, V, 332.

${ }^{77}$ Mizzî, Tehzîbü'l-Kemâl, VI, 106; İbn Hacer, Tehzîbü't-Tehzî̀, V, 333.

${ }^{78}$ Mizzî, Tehzîbü'l-Kemâl, VI, 108.

${ }^{79}$ Mizzî, Tehzî̉ü'l-Kemâl, IV, 332; İbn Hacer, Et-Takrîb, s. 272.

${ }^{80}$ Mizzî, Tehzîbü'l-Kemâl, IV, 332.

81 İbn Hacer, Et-Takrîb, s. 272.

${ }^{82}$ Mizzî, Tehzîbü'l-Kemâl, IV, 332.

${ }^{83}$ İbn Hibbân, Sikât, V, 177.

84 İbn Hibbân, Sikât, VI, 417; Mizzî, Tehzîbü'l-Kemâl, V, 431-433.

${ }^{85}$ Mizzî, Tehzîbü'l-Kemâl, V, 433.

${ }^{86}$ İbn Hibbân, Sikât, VI, 417.
} 


\section{Ebu'l-Ahves:}

Sellâm b. Süleym el-Hanefî, Ebû'l-Ahves el-Kûfî, Kütüb-i sitte râvilerindendir. Rivâyette bulunduğu muhaddisler arasında Esved b. Kays, A'meş, Ebû İshâk ve Mansûr bulunmaktadır. ${ }^{87}$ Yahyâ b. Maîn, Ebû Zür'a ve Nesâî "sika" demişlerdir. ${ }^{88}$ İbn Hacer "sika ve mutkin" demiştir. ${ }^{89}$

\section{Ebû Bekr b. Ebî Şeybe:}

Abdullah b. Muhammed b. Ebî Şeybe el-Kûfî, pek çok kimseden rivâyet almış ve pek çok kimseye rivâyet vermiştir. ${ }^{90}$ Iclî, Ebû Hâtim, İbn Hırâş ${ }^{91}$ ve İbn Hacer, " sika ve hafız"92 demişlerdir.

\subsubsection{Senedin Değerlendirilmesi}

Râviler üzerinde yapılan inceleme neticesinde cerh edilen herhangi bir râvinin bulunmaması sebebiyle bu rivâyetin sahih olduğu sonucuna ulaşılmıştır.

\subsection{Rivâyetlerin Genel Değerlendirilmesi}

Hz. Âişe'den seccadeyi getirmesini istediği rivâyetler, muttasıl senetlerle $\mathrm{Hz}$. Peygamber'e ulaşan merfu rivâyetlerdir. Hz. Peygamber'den sonra iki tabakada birer râvi tarafından rivâyet edildiği için rivâyetler ferttir. Râvilerin durumları incelediğinde, cerh edilen bir râviye rastlanılmamıştır. Bu durumda ilgili rivâyetleri sahih olarak değerlendirilmesi uygundur.

Peygamber Efendimizin Hz. Âişe'den mescidde olduğunu bildiği halde seccadeyi istemesi, bunun üzerine Hz. Âişe'nin “ben hayızlıyım” şeklinde karşılık vermesi, onda var olan bir takım kaygıları akla getirmektedir. Hz. Peygamber'in Hz. Âişe'ye "Hayız senin elinde değildir" şeklinde vermiş olduğu cevabın, toplumda kadınlara karşı özellikle hayızlı kadınlara karşı mevcut olan olumsuz algının kaldırılmasına yönelik bir adım olduğunu düşünmek mümkündür.

Nitekim Hadis Kitaplarında Yer Alan; “Hayızlı Kadının, Kocasının Başını Yıkaması Ve Taraması Bâbı", "Erkeğin, Kadın Hayızlı İken Karısının Kucağında Kur'ân Okuması Bâbı", "Hayızlı Kadının Cildine Dokunmak Bâbı", "Hayz Elbisesi İçinde İken Hayızlı Kadınla Beraber Uyumak Bâbı", "Hayızlı Kadınlarla Birlikte Yemek Yiyip İçmek”, "Hayız Gören Kadının Artığından İstifade Etmek”, "Hayızlı Kadın Kocasına Hizmet Edebilir Mi?”, “Lohûsa (İken Ölen) Kadın Üzerine Cenaze Namazı Ve Bu Namazın Sünneti Bâbı" gibi bâb başlıklarından hayızlı kadının günlük hayata katılımı ile ilgili konunun ne kadar detaylı olarak incelendiğini anlayabiliriz.

Şüreyh (r.a), babasından naklederek şöyle diyor: Hz. Âişe’ye: “Hayız gören kadın kocası ile yemek yiyebilir mi?" diye sordum: Âişe (r.anha): "Evet, Rasûlullah (s.a.v) beni

\footnotetext{
87 İbn Hibbân, Sikât, VI, 417; Mizzî, Tehzîbü'l-Kemâl, III, 344.

${ }^{88}$ Mizzî, Tehzîbü'l-Kemâl, III, 344.

89 İbn Hibbân, Sikât, VI, 417; İbn Hacer, Et-Takrîb, s. 425.

${ }^{90}$ Mizzî, Tehzîbü'l-Kemâl, IV, 265-266.

${ }^{91}$ Mizzî, Tehzîbü'l-Kemâl, IV, 266.

92 İbn Hacer, Et-Takrîb, s. 540
} 
çağııır, hayızlı olduğum halde O'nunla yemek yerdim. Et parçasın alır bana verir bende ondan ısırırdım sonra sofraya bırakırdım. Rasûlullah (s.a.v), o et parçasını alır benim ısırdığım yerden yerdi. İcecek bir şeyler ister, bana verir o içmeden ben içerdim ve kabı bırakırdım. Rasûlullah (s.a.v) de o kabı alır benim içtiğim ve ă̆zıma aldı̆̆ım yerden içerdi."

Âişe (r.anha)'dan rivâyete göre, şöyle demiştir: "Rasûlullah (s.a.v), başını bana uzatır ben de hayızlı olduğum halde O'nun başını itikafta oldu ̆̆u halde yıkardım." ${ }^{4}$

Hadis kitaplarında yer alan bu ve benzeri rivâyetleri okuduğumuz zaman aklımıza gelen hayızlı kadınlar hakkında toplumda farklı algılar olduğu yönündeki düşünce adeta perçinlenmektedir. Nitekim cahiliye döneminde insanlar, Yahudilerde olduğu gibi kadın adet olduğunda onunla yemezler, içmezler, oturmazlar, bir yatakta yatmazlar hatta aynı evde bile yaşamazlardı. ${ }^{95} \mathrm{~Hz}$ Peygamber uygulamalarıyla hayızlı kadının temiz olmayan yönünün sadece âdet kanı olduğunu, tükürüğü ve terinin pis olmadığını, pişirdiği yemeğin yeneceğini ve yemek artığının da temiz olduğunu anlatmıştır. Yukarıda geçen hadis, hayızlı kadının artığının ve bedeninin temiz olduğuna delildir. Yahudilerin yaptığı gibi kadınları terk etmek değil, onlarla beraber olmak, yemek, içmek, şaka yapmak gibi hareketlerde bulunmak gerektiğinin ifadesi vardir.

Diğer bazı dinlerde ve toplumlarda görüldüğü gibi hayızlı kadın İslâmiyet'te pis sayılmamış, günlük hayattan, özel ve sosyal ilişkilerden uzak tutulmamıştır. Rasûlullah (s.a.v)'in bu konuda düzenleyici çeşitli hadisleri bulunmaktadır. "Bu hayız, Allah'ın, Âdem (a.s.)in kızlarına yazdığı bir haldir." 96 Âdet gören eşinden ayrı ve uzak mı kalacağını soran sahâbeye Allah'ın elçisi şöyle cevap vermiştir: “Cinsel ilişki dışındaki şeyler, normal zamanlardaki gibi yapılabilir. ${ }^{97}$ Ancak, bu durumdaki bir kadının göbeği ile diz kapağ̊ arasının örtülü olması yeterli görülmüştür." 98

Enes b. Mâlik (r.a.) demiştir ki; "Yahudiler, bir kadın hayız olduğunda, onu evden çıkarırlar, onunla beraber yemezler, içmezler ve aynı evde birlikte bulunmazlardı. Bu durum Rasûlullah (s.a.v.)'e soruldu. Bunun üzerine Cenâb-ı Allah: "Sana kadınların ay hâlini de sorarlar. De ki, o bir ezadır. Onun için hayız zamanında kadınlardan ayrı kalın..." (Bakara 222) mealindeki âyeti indirdi; Rasûlullah da: "Onlarla birlikte evlerde oturunuz ve cinsî temastan başka her şeyi yapınız" buyurdu.

Bunun üzerine Yahudiler: "Bu adam, bizim (dinimizin) işinden hiçbir şey birakmadan hepsine muhalefet etmek istiyor" dediler. (Bunu duyan) Üseyd b. Hudayr ve Abbâd b. Bişr Peygamber (s.a.v.)'e geldiler ve: "Ya Rasûlullah, Yahudiler şöyle şöyle diyorlar (onlara muhalefet olsun diye) hayızlı kadınlarla (cinsî) temasta da bulunsak mı?" dediler. Rasûlullah (s.a.v.) (mübarek) yüzünün (rengi) değişti, hatta biz onlara kızdığını zannettik. Bu iki zat (Rasûlullah'ın huzurundan) çıkmışlardı ki Rasûlullah'a

\footnotetext{
${ }^{93}$ Müslim, Hayız 3; İbn Mâce, Tahâret 125; Nesâî, Hayız 14.

${ }^{94}$ Buhârî, Hayız 3; Nesâî, Hayız 3.

${ }^{95}$ Harman Ömer Faruk, "Havvâ", DİA, XVI, 543; Levililer, 15: 19-28.

${ }^{96}$ Buhârî, Hayız 1,7; Edahi 3,10; Müslim, Hacc 119, 120; Ebû Dâvûd, Menâsık 23.

${ }^{97}$ Müslim, Hayız 16; İbn Mâce, Tahâret 12; Nesâî, Tahâret 18.

${ }^{98}$ Dârimî, Tahâret 108; Buhârî, Hayız 5, Tahâret 175.
} 
hediye olarak süt getiren biri ile karşılaştılar. Resûlullah (s.a.v) peşlerinden gönderip kendilerine (bu sütten) içirdi. Böylece biz de Rasûlullah'ın onlara kızmadığını anladik."99

Hadis-i şeriften anlaşıldığına göre; Yahudiler ay hâli olan bir kadını evlerinden ayırırlar; onlarla birlikte yemeyi, içmeyi ve bir arada oturmayı terk ederlerdi. Müslümanlar Rasûlullah'a hayızlı kadınlara ait durumun ne olacağını sorunca Bakara Süresinin 222. ayeti nazil oldu. ${ }^{100}$ Bazı Müslümanlar, bu ayetteki "aybaşı hâlinde kadınlardan ayrı kalın" ifadelerini görünce, bu ayrılmanın Yahudilerin yaptıkları gibi kadınları terk etmek şeklinde olduğunu zannettiler. Bir kısım sahâbiler Rasûlullah'a gelerek; "Ya Rasûlullah soğuk şiddetli, elbise az, eğer kadınları tercih edecek olursak, ev halkı helak olacak, ev halkını tercih edersek kadınlar zarar görecek. Ne yapalım?" diye sordular. Rasûlullah (s.a.v.) kendilerine şu cevabı verdi: "Sizin emrolunduğunuz onlara yaklaşmamanızdır; onları evden çıkarmanız değil." 101

Sahâbenin nassın delaletini yanlış anlamalarının tek örneği bu ayet değildir. ${ }^{102}$ Nitekim yine Hz. Peygamber'in "Hayız senin elinde değildir" sözündeki "el'in" delaletini farklı yorumlamışlardır. Bunun neticesinde hadisi "Hz. Âişe'nin eli hayızlı değildir" şeklinde anlayarak fetvalar vermişlerdir. Mesela Şâfiîler âdetli olan kadınların keyfi bir şekilde mescidlerde oturmalarını, mescidleri ihtiyaç dışında kullanmalarını haram olarak görmekle birlikte, içerisinden geçmek veya orada bir şeyi alıp bırakmak gibi herhangi bir ihtiyaçları olduğu durumlarda mescidlere girebileceğini ifade etmiştir. Ancak herhangi bir gerekçeleri olmadığ 1 halde mescidin içerisinden geçmeyi de mekruh olarak görmüştür. ${ }^{103}$ Şevkânî (ö.1250/1834) de mescidden geçmeyi caiz görmüştür. ${ }^{104}$

Kısaca bu rivâyete dayanarak verilen fetvalarda, âlimlerimizin kılı kırk yararak özel hallerinde kadının mescide girmesi konusunu detaylandırmış oldukları görülmektedir. Özel hallerinde olan kadınların mescide ve müştemilatına girmelerinin kesin bir ifadeyle haram olduğunu belirtmişler ancak mescidin bahçesini ve cenaze namazı kılınan yerleri müstesna görmüşlerdir. Bununla birlikte bu mezhepler, düşman korkusu, yırtıcı hayvanlardan korunma gibi zaruri haller dolayısıyla kişinin teyemmüm ile mescide girmesini caiz görmüş, ${ }^{105}$ hayızlı kadının mescidin bir kapısından girip diğerinden çıkması caizdir ama girdiği kapıdan çıkması mescidde dolaşma anlamına geldiği için haramdır denilmiştir. Ayrıca gusül için gerekli su ve su

\footnotetext{
${ }^{99}$ Müslim, Hayız 3; Nikâh 46; Nesâî, Hayız 8; Ebû Dâvûd, Tahâret 102.

100 Kastallânî, Ebü'l-Abbâs Şihâbüddîn Ahmed b. Muhammed b. Ebî Bekr el-Kastallânî, İrşâdü's-Sâri, (Misır: Matbaatü'l-Kübrâ h. 1323), I, 340.

101 Zemahşerî, Cârullah Ebî'l-Kâsım Mahmûd bin Ömer, el-Keşşâf, haz. Adil Ahmed Abdi'l-Mevcûd, (Riyâd: Mektebetü'1-Abîkân 1998.), I, 262; Ahmed b. Ali b. Hacer el-Askalâni, Fethu'l-Bâri Şerhu Sahihi'lBuhârî, (Riyâd: Dâru's-Selâm 2000), I, 518.

102 Bkz. Bakara 187.

103 İbn Rüşd, Bidâyetü'l-Müctehîd, I, 48.

104 Şevkânî, Ebû Abdillah Muhammed b. Ali bin Muhammed el-Havlâni, Neylü'l-Evtâr min Esrâri Münteka'l-Ahbâr, haz. Enver el-Bâz, (Misır: Dâru'l-Vefa 2008), I, 288.

${ }^{105}$ Cezîrî Abdurrahman, Dört Mezhebe Göre İslâm Fıkhı, (İstanbul: Çağrı Yayınları 1993), I, 104.
} 
kabı gibi lüzumlu bir eşya mescidde bulunursa oraya girip onu alabileceklerini de ifade etmişlerdir. ${ }^{106}$

"Sana kadınların ay hâlini de sorarlar. De ki, o bir ezadır. Onun için hayız zamanında kadınlardan ayrı kalın..." 107 mealindeki âyet, kadınlarla özel hallerinde iken cinsel ilişkiyi haram kılmıştır. Âlimler, hayızlı kadının mescide girmesi konusunda gösterdikleri katı tutumu bu konuda göstermemişlerdir. Ebû Hanife de dâhil İslâm âlimlerinin çoğuna göre "bir kimse, henüz âdetini tamamlamamış olan eşi ile cinsel ilişkiye girerse günahkâr olur. Allah'a bol bol tevbe ve istiğfar etmekten başka yapabileceği bir şey yoktur." İbn Abbâs, Katâde, Evzâî ve Ahmed b. Hanbel'e göre fakir müslümanlara 1 $\left(4,25\right.$ gr. altın) veya yarım dinar sadaka vermesi gerekir. ${ }^{108}$ Yaşadığımız toplumda Kur'ân'da hayızlı kadınla cinsel ilişkiye girmenin haram olduğunu bildiren bir ayetin olduğunun son yıllarda öğrenildiğini de unutmamak gerekir. Buna karşılık "hayızlı kadın asla mescide giremez, büyük günahtır" bilgisi ise kızlara çocuk yaşlardan itibaren öğretilmektedir.

\section{Hz. Peygamber'in Sahâbilere Evlerinin Kapılarının Yönünü Değiştirmelerini Emrettiği Rivâyet}

Hz. Peygamber'in sahâbilere, evlerinin mescide açılan kapılarının yönünü değiştirmelerini emrettiği rivâyet, Ebû Dâvud ve İbn Mâce'de yer almaktadır.

\subsection{Ebû Dâvud'da Bulunan Rivâyet}

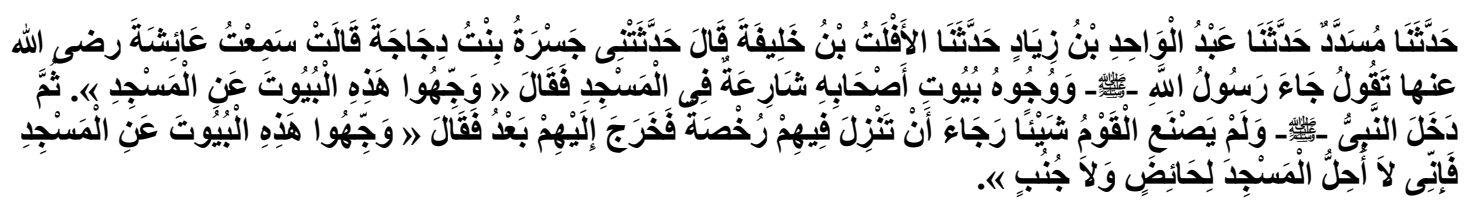

“Bize Müsedded, Abdü'l-Vâhid b. Ziyâd'dan, o da Eflet b. Halîfe'den, o da Cesratü bnt. Dicâce'den, Âişe (r.anhâ)'nın şöyle dediğini rivâyet etmiştir: Sahâbilerin evlerinin kapıları mescide açılmış bir halde iken, Rasûlullah (s.a.v.) (Mescide) gelip "Şu evlerin yönlerini (kapılarını) mescidden çeviriniz" buyurdu ve (hucre-i saadetine) girdi. Ashab, kendileri hakkında bir ruhsat inmesini umarak bir şey yapmadılar. (Evlerin kapılarını çevirmediler.) Bir müddet sonra Rasûlullah onlar (ın yanına) tekrar çıktı ve "Şu evlerin (kapılarını) çeviriniz. Çünkü ben, mescidi hayız ve cünüp (olan)lara helâl görmüyorum" buyurdu."109

\section{Ebû Dâvûd $\Rightarrow$ Müsedded $\Rightarrow$ Abdü'l-Vâhid b. Ziyâd $\Rightarrow$ Eflet b. Halîfe $\Rightarrow$ Cesratü bnt. Dicâce $\Rightarrow$ Hz. Âişe $\Rightarrow$ Hz. Peygamber}

Hanefilerin ${ }^{110}$ delil olarak gösterdikleri bu rivâyetin senedindeki bazı râvilerin güvenirlilik durumu şöyledir:

\footnotetext{
${ }^{106}$ Cezîrî, Dört Mezhebe Göre İslâm Fıkhı, I, 105.

107 Bakara 222.

${ }^{108}$ Bardakoğlu Ali, İlmihal II, (Ankara: Diyanet İşleri Başkanlığı Yayınları 2006), s.19.

${ }^{109}$ Ebû Dâvûd, Tahâret 94.

${ }^{110}$ Mergînânî, Alî b. Ebî Bekr b. Abdi'l-Celîl el-Ferğânî, el-Hidâye fî Şerhi'l Bidâyetü'l-Mübtedî, (Beyrût: Dâru Ahyâ'it-Türâsi'l-Arabî h.1417), 1, 209; el-Mevsılî, el-İhtiyâr, c.1, s.13.
} 


\section{Cesratü bnt. Dicâce:}

Cesratü bnt. Dicâce el-Âmirî el-Kûfî’nin, Alî b. Ebî Tâlib, Ebû Zer Ğıffari, Hz. Âişe ve Ümmü Seleme' den rivâyetleri vardır. Kendisinden Ömer b. Umeyr b. Mahdûc, Eflet b. Halîfe rivâyette bulunmuştur. ${ }^{111}$ Iclî, "tabiî ve sika"112; İbn Hacer ise "makbül" demiştir. ${ }^{113}$

\section{Eflet b. Halîfe:}

Eflet b. Halife el-Amirî ez-Zühlî, künyesi Ebû Hasan el-Kûfî'dir. ${ }^{114}$ Cesratü bnt. Dicâce ve Düheyme bnt. Hassân'dan rivâyet etmiş; kendisinden de Süfyân es-Sevri, Ebû Bekr b. Ayyâş rivâyette bulunmuştur. Ahmed b Hanbel, "bir sakınca görmediğini"; Ebû Hâtim, "sika"; Dârekutnî "sâlih"115 İbn Hacer ise "makbül" olduğunu söylemişlerdir. ${ }^{116}$

\section{Abdï'l-Vâhid b. Ziyâd:}

Abdü'l-Vâhid b. Ziyâd el-Abdî, el-Basrî, İbn' ü'l-Cevzî ed-Duafâ kitabında zikretmiştir. Yahyâ, Abdü'l-Vâhid için "leyse bişey"; Muhammed b. Sa'd, Ebû Zür'a, Ebû Hâtim, Ebû Dâvud, Iclî117 ve İbn Hacer, "sika", 118 Nesâî , "leyse bihi be's (zararı yok)" demişlerdir. ${ }^{119}$ Hicri 176 yılında vefat etmiştir. ${ }^{120}$

\section{Müsedded:}

Müsedded b. Müserhed b. Müserbel el-Esedî, künyesi Ebû'l-Hasan Basrî́dir. ${ }^{121}$ Ebû Hâtim, Iclî, Nesâî ve İbn Hacer, "sika" demişlerdir. ${ }^{122}$ Hicri 176 yılında vefat etmiştir. ${ }^{123}$

\subsection{Senedin Değerlendirilmesi}

Şevkânî124 ve Zeylâî, ${ }^{125}$ bu rivâyetin sahih olduğunu söylemişlerdir. Buna mukabil İbnü'l-Münzir (ö. 318/930), İbn Rüşd, ${ }^{126}$ Hattâbî (ö. 388/998), ${ }^{127}$ İbn Hazm (ö.

\footnotetext{
${ }^{111}$ Mizzî, Tehzîbü'l-Kemâl, VIII, 523; İbn Hibbân, Sikât, IV, 121.

112 Mizzî, Tehzîbü'l-Kemâl, VIII, 523.

113 İbn Hacer, Et-Takrîb, s. 1348.

114 İbn Hibbân, Sikât, VI, 88; İbn Hacer, Et-Takrîb, s. 151.

${ }^{115}$ Mizzî, Tehzîbü'l-Kemâl, I, 281.

116 İbn Hibbân, Sikât, VI, 88; İbn Hacer, Et-Takrîb, s. 151.

${ }^{117}$ Mizzî, Tehzîbü'l-Kemâl, V, 7; İbn Hacer, Tehzîbü't-Tehzîb, IV, 278.

118 İbn Hacer, Et-Takrîb, s. 630.

${ }^{119}$ Mizzî, Tehzî̉ü'l-Kemâl, V, 8.

120 İbn Hibbân, Sikât, VI, 88.

${ }^{121}$ İbn Hibbân, Sikât, IX, 200, Mizzî, Tehzî̉ü'l-Kemâl, VII, 83.

${ }_{122}$ Mizzî, Tehzîbü'l-Kemâl, VII, 84; İbn Hacer, Et-Takrîb, s. 930.

${ }^{123}$ İbn Hibbân, Sikât, IX, 200.

124 Şevkani, Neylü'l-Evtar, I, 324.

${ }^{125}$ Zeylaî, Ebû Muhammed Cemâlüddîn Abdullāh b. Yûsuf b. Muhammed ez-Zeylaî, Nasbu'r-Râye li Ehâdîsi'l-Hidâye, haz. Muhammed Avvâme, (Beyrût: Dâru'l- Kütübi'l- İlmiyye 2010), I, 254.

126 İbn Rüşd, Bidâyetü'l-Müctehîd, I, 101.

127 Hattâbî, Ebû Süleymân Hamed bin Muhammed b. İbrâhîm el-Hattâbî el-Büstî, Meâlimü's-Sünen, haz. Muhammed Ragıb et-Tabbâh, (Halep: Matbaâtü'l-̇̇lmiyye 1932), I, 78.
} 
456/1064), ${ }^{128}$ Beğavî (ö. 516/1117) ${ }^{129}$ ve İbn Receb (ö. 595/1198) ${ }^{130}$ ise rivâyetin sahih olmadığını söylemişlerdir. Bu rivâyetin münekkitler tarafından sahih kabul edilmemesinin gerekçesi üç noktada toplanmaktadır:

a- Eflet b. Halîfe, bazılarına göre meçhuldür.

b- Cesratü bnt. Dicâce ismindeki “د” harfinin, meftuh veya meksur okunması konusunda ihtilaf vardır. Buhârî, Dicâce için "acaib" demiştir.

c- Hz. Âişe'den rivâyet edilen bu haber sadece Ebû Dâvud'un Sünen'in de yer almaktadır. Yine Ümmü Seleme rivâyeti de sadece İbn Mâce'de geçmektedir. ${ }^{131}$

\section{3. İbn Mâce'de yer alan rivâyet}

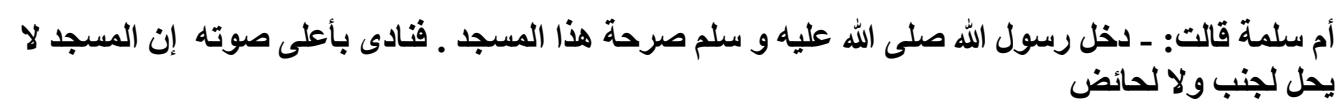

“Ümmü Seleme (r.a.)'dan rivâyet edildiŏine göre şöyle demiştir: Resûlullah (s.a.v.) bu mescidin avlusuna girerek en yüksek sesiyle: "Şüphesiz mescid, cünüb adama ve hayızlı kadına helâl değildir." buyurdu."132

Bu rivâyetin senedi şöyledir:

\section{Ebû Bekr b. Şeybe ve Muhammed b. Yahyâa Ebû Nuaym $\Rightarrow$ Ebû Ğaniyye Ebû́'l-Hattâb el-Hecerî $\Rightarrow$ Mahdûc ez-Zuheylî̄ $\Rightarrow$ Cesratü binti Dicâce $\Rightarrow$ Ümmü Seleme}

Râvilerin incelemesi şöyledir:

\section{Mahdûc ez-Zuheylî:}

Mahdûc ez-Zuheylî el-Bâhilî̀nin, İbn Mâce'de tek rivâyeti bulunmaktadır. ${ }^{133}$ İbn Hacer "meçhûl" demiştir. ${ }^{134}$

\section{Ebû'1-Hattâb el-Hecerî:}

Amr veya Ömer b. Umeyr, İbn Mâce'de rivâyeti bulunmaktadır. ${ }^{135}$ İbn Hacer, "meçhûl" demiştir. ${ }^{136}$

\footnotetext{
128 İbn Hazm el-Endelüsî, el-Muhallâ bi'l-Âsâr, (Beyrût: Dâru'l-Kütübi'l-İlmiyye, 2010), I, 401.

${ }_{129}$ Beğâvi, Hüseyin bin Mes'ud bin Muhammed el- Ferrâ, Şerhu's-Sünne, (Beyrût: Dâru'l-Efkâr 2005), I, 349.

130 İbn Receb el-Hanbelî, Ebü'l-Ferec Zeynüddîn Abdurrahmân b. Ahmed b. Abdirrahmân Receb elBağdâdî ed-Dımaşki, Fethu'l-Bâri alâ Sahîhi'l-Buhârî, (Medine: Mektebü'l-Ğurebaü'l-Eseriyye 1996), I, 322.

${ }^{131}$ Adve, Selman b. Fahd el-Adve, Bulûğu'l-Merâm Şerhi, (Riyâd: Mektebetü'r-Rüşd 2006), III, 1139

132 İbn Mâce, Tahâret 126; Bu rivâyetin farklı metinleri de bulunmaktadır: Ebû'l-Kâsım Amidî, Bedru'l-

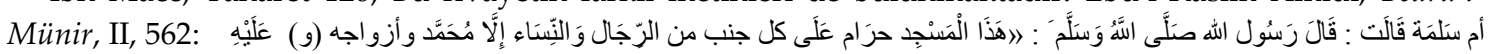
مَكَّي (وَفَاطِمَة) i İbn'ü'l-Kayyım el-Cevziyye, Ebû Abdillâh Şemsüddîn Muhammed b. Ebî Bekr b. Eyyûb ez-

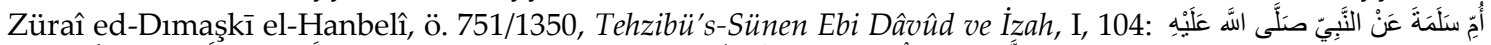

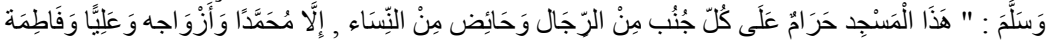

${ }^{133}$ Mizzî, Tehzî̉ǘl-Kemâl, VII, 46.

${ }^{134}$ İbn Hacer, Et-Takrîb, s. 923.

${ }^{135}$ Mizzî, Tehzîbü'l-Kemâl, VIII, 300.

136 İbn Hacer, Et-Takrîb, s. 1140.
} 


\section{Ebû Ğaniyye:}

Hamîd b. Ebî Ğaniyye el-Esbahânî, İbrâhîm en-Nehaî, Abdullah el-Muhârik'ten rivâyet etmiştir. Süfyan es-Sevrî de ondan rivâyet almıştır. Buhârî, Edebü'l-Müfred'te ondan bahsetmiştir. ${ }^{137}$ İbn Hacer, "sadûk" demiştir. ${ }^{138}$

\section{Ebû Nuaym:}

Adı İshâk b. el-Fürât b Ca'd b. Süleym et-Tüciddiî olup künyesi Ebû Nuaym elMisrî'dir. Ebû Avâne, Ebû Nuaym'ın "sika"; Ebû Hâtim, "şeyhtir fakat meşhur değildir"139 olduğunu söylemişlerdir. İbn Hacer, "sadûk" demiştir. ${ }^{140}$

\section{Ebû Bekr b. Ebî Şeybe:}

Abdullah b. Muhammed b. Ebî Şeybe el-Kûfi, pek çok kimseden rivâyet almış ve pek çok kimseye rivâyet vermiştir. ${ }^{141}$ Iclî, Ebû Hâtim, İbn Hırâşs ${ }^{142}$ ve İbn Hacer, "sika ve hafız"143 demişlerdir.

\subsection{Senedin Değerlendirilmesi}

Hadis, Hz. Peygamber'den sonra her tabakada birer râvi tarafından nakledilmesi sebebiyle ferd/gariptir. Her ne kadar senette sika râviler bulunsa da Mahdûc ve Ebu'l-Hattâb'ın meçhul olması, Ebû Ğaniyye hakkında fazla bir malumatın olmaması sebebiyle bu rivâyet zayıftır. Metinle ilgili olarak da pek çok kimsenin duyduğu bir olayın meçhul râviler tarafından aktarılması da dikkate alınması gereken noktalardandır.

Hattâbî, bu hadisin âlimler tarafından zayıf kabul edildiğini, Eflet'in rivâyetinin meçhul olduğunu bu sebeple âlimlerin Eflet'in hadisiyle ihticac etmenin doğru olmadığını söylediklerini nakletmiştir. ${ }^{144}$

\section{Hayızlı Halde Mescide Girmek İle İlgili Rivâyetlerin Değerlendirilmesi}

Yapılan senet incelemeleri neticesinde, "Kadınların bayram namazına çıkış" rivâyetleri ile "Hz. Peygamber'in Hz. Âişe'den seccadeyi getirmesini istediği" rivâyetlerin sahih olduğu sonucuna ulaşılmıştır. Hz. Peygamber'in sahâbilere evlerinin kapılarının yönünü değiştirmeleri emrettiği rivâyet ise zayıftır. Bu bilgilerin neticesinde, hayızlı kadının mescide girmemesi konusunda delil olarak gösterilen rivâyet zayıftır. Ahkâm konusunda sahih hadislerin delil olarak gösterilmesi gerekir. Hz. Peygamber'in hayızlı kadınların mescide girmesinde bir sakınca görmediği diğer iki hadisten anlaşılmaktadır.

\footnotetext{
${ }^{137}$ Mizzî, Tehzîbü'l-Kemâl, II, 306.

138 İbn Hacer, Et-Takrîb, s. 275.

${ }^{139}$ Mizzî, Tehzîbü'l-Kemâl, I, 196; İbn Hacer, Et-Takrîb, s. 130.

${ }^{140}$ İbn Hacer, Et-Takrîb, s. 131.

${ }^{141}$ Mizzî, Tehzîbü'l-Kemâl, IV, 265-266.

${ }^{142}$ Mizzî, Tehzîbü'l-Kemâl, IV, 266.

143 İbn Hacer, Et-Takrîb, s. 540.

144 Zeylaî, Nasbu'r-Râye, I, 255.
} 


\section{Sonuç}

Kadınların özel hallerinde mescidlere girip giremeyeceği konusundaki İslam âlimlerinin görüşlerinin dayandıkları rivâyetleri yukarıda verildi. Özel hallerinde kadınların mescidlere girip giremeyeceği ile ilgili görüşler incelendiğinde bu görüşlerin birbirinden oldukça farklı olduğu görülmektedir.

Konu şer'î hüküm içerdiği için hüküm, Kur'an ve sünnet kaynaklı olmalıdır. Mescide girmeyi tamamen yasaklayanlar ile mutlak manada caiz görenlerin naslardan birtakım delilleri vardır. Bazen müçtehitler aynı nassı farklı yorumlayabilmektedir. Bazen de birinin sahih kabul ederek üzerine hüküm oluşturduğu rivayeti diğer bir mezhep veya âlim zayıf hatta yok saymaktadır. Yine âdetli kadınların mescidlere o halde girmelerini âlimler farklı farklı illetlere bağlamaktadır. Bazıları âdetli kanının mescidi kirletme korkusunu, kimisi mescidlerin kutsiyetinin zedelenmesini illet saymakta, kimisi de nassın zahirine sığınmaktadır.

Konumuzla ilgili delilleri değerlendirmek gerektiğinde karşımıza ilk olarak İslam âlimlerinin görüşlerini dayandırdıkları Nisa Sûresi 43. ayet çıkmaktadır. Hanefî fakihlerin de bahsettiği üzere "namaza yaklaşmayın" ayetini "namaz kılınan yere yaklaşmayın" şeklinde yorumlamak Kur'an'ın zahirine aykırı görünmektedir. Açı delil de bulunmadığına göre bu ayete dayanarak kadınların özel hallerinde mescidlere giremeyeceklerini savunmak zordur. Hanefî fakih-müfessir Cessâs'ın da açıkladığı gibi Kur'an'ın hakikat manasını mecazî manaya hamletmek için delil bulunması gerekir.

İkinci olarak yapılan senet incelemeleri neticesinde, "Bayram namazına çıkış" rivayetlerin ve "Hz. Âişe' den seccadeyi getirmesini istediği" rivâyetlerin, sahih olduğu sonucuna ulaşılmıştır. Bu rivâyetler ışı̆̆ında Hz. Peygamber'in, hayızlılar da dâhil tüm kadınları bayram namazlarına çağırmış olduğu ve bayram namazlarını mescidin içinde değil de açık bir meydan olan musallâ denilen yerde kıldığı bilinmektedir. Musalla elbette mescid değildir ama namaz kılmak için toplanılan bir mekândır. Hz. Peygamber ise her durumda kadınları namaz kılınan bir mahalle davet etmiştir. Ayrıca yağmurlu zamanlarda bayram namazını mescidde kıldıkları bilinmektedir. Eğer Hz. Peygamber hayızlı kadınların mescide girmesinde bir sakınca görmüş olsaydı, yağmurlu günlerde mescidde toplanırlarken gerekli uyarıları yapardı. Yine $\mathrm{Hz}$. Peygamber'in Hz. Aişe'den mescidde bulunan seccadeyi kendisine getirmesini istemesi ve onun hayızlı olduğunu belirtmesine rağmen Hz. Peygamber'in elinin temiz olduğunu belirtmesi kadınların mescidlere girebileceğine işaret etmektedir.

"Sahâbilere evlerinin kapılarının yönünü değiştirmelerini emrettiği rivâyet", Hz. Peygamber'den sonra her tabakada birer râvi tarafından nakledilmesi sebebiyle ferd/gariptir. Her ne kadar senette sika râviler bulunsa da Mahdûc ve Ebu'l-Hattâb'ın meçhul olması, Ebû Ğaniyye hakkında fazla bir malumatın olmaması sebebiyle bu rivâyet zayıftır. Metinle ilgili olarak da pek çok kimsenin duyduğu bir olayın meçhul râviler tarafından aktarılması dikkate alınması gereken noktalardandır. Bu bilgiler neticesinde, hayızlı kadının mescide girmemesi konusunda delil olarak gösterilen rivâyetlerin zayıf olduğu sonucuna ulaşılmıştır. 
Konuyla ilgili rivayetlere bir bütün olarak baktığımızda Rasulullah döneminde kadınların mescidlere devamlı olarak gittiklerini görmekteyiz. Hatta mescidlere gitme konusunda kadınlara engel olmak isteyenleri Hz. Peygamber uyarmıştır. Rasulullah'ın vefatından sonra fitne söylemi sebebiyle kadınlar toplumsal hayattan olduğu gibi mescidlerden de uzaklaştırılmıştır. Oysa bugün kadınlar, ibadet etme, vaaz etme ve vaaz dinleme, Kur'an dersi verme ve alma, kültürel etkinlikler, toplantı yapma, dinlenme, turistik ziyaret, konaklama gibi pek çok sosyo-kültürel amaç veya ihtiyaçlarla mescidlere girmektedirler.

Sonuç olarak kadınların özel hallerinde iken mescide girmelerini yasaklayan sahih bir rivayet bulunmamaktadır. Müctehitlerin fetva verirken görüşlerini zorunlu olarak bir ayet veya hadise dayandırmadıkları bilinmektedir. Âlimlerimizin fetvâ hazırlarken görüşlerini dinî yönden sağlam bir delile dayandırması ve Şâri'in maksadını karşılaması yanında halkın ihtiyacını da karşılıyor olması gerekmektedir. Aynı zamanda hades halinde mescidlere girilmesinin mutlak anlamda yasaklandığını savunmak, belirli olaylar üzerine varid olan nasların, nedenlerini ve niçinlerini göz ardı etmek anlamına gelmekte ve bu sahadaki ilk dönem uygulamaları ile çelişmektedir.

Bu sebeplerle kadınların özel hallerinde cami adabına dikkat edildiği takdirde mescide girmesinin, sosyal ve kültürel gerekçelerle orada bulunmasının, mescid ve müştemilatından faydalanmasının caiz olacağı düşünülmektedir.

\section{Kaynakça}

Adve, Selman b. Fahd el-Adve, Bulû̆ğu'l-Merâm Şerhi, Riyâd: Mektebetü'r-Rüşd 2006.

Aynî, Ebû Muhammed (Ebü's-Senâ) Bedrüddîn Mahmûd b. Ahmed b. Mûsâ b. Ahmed el- Aynî, Umdetü'l-Kâri fi Şerhi Sahîhi'l-Buhârî, Beyrût: Dâru'l- Kitâbi'l-İlmiyye 2005.

Bardakoğlu, A. İlmihal II, Ankara: Diyanet İşleri Başkanlığı Yayınları 2006.

Beğâvi, Hüseyin bin Mes'ud bin Muhammed el- Ferrâ, Şerhu's-Sünne, Beyrût: Dâru'l-Efkâr 2005.

Bozkurt, Nebi - Küçükaşcı Mustafa Sabri, "Mescid-İ Nebevî", TDV İslâm Ansiklopedisi, C:XXIX, Türkiye Diyanet Vakfı Yayınları, İstanbul 2004, s. 281-290.

Buhârî, Ebû Abdullah Muhammed b. İsmâîl b. İbrâhîm el-Cu'fî el-Buhârî, el-Câmiu's-Sahîh, Riyâd: Beytu'l-Efkâr 1998.

Cezîrî, Abdurrahman, Dört Mezhebe Göre İslâm Fikhı, İstanbul: Çağrı Yayınları 1993.

Dalgın, Nihat, Gündemdeki Tartışmalı Dini Meseleler, İstanbul: Ensar Neşriyat 2014.

Dârimî, Ebû Abdullah bin Abdu'r-Rahmân b. Fadl bin Behram, Sünenü'd-Dârimî, haz. Hasan Selim Esed, Riyad: Dâru'l-Muğanni 2000.

Diyanet İşleri Başkanlığı, Aile İle İlgili Sıkça Sorulan Sorular, Ankara: Diyanet İşleri Başkanlığı Yayınları, 2015.

Ebû Dâvud, Süleymân b. Eşâsî el-Ezdî es-Sicistânî, Kitabü'-Sünen, haz. Muhammed Avvâme, Beyrût: Müessesetü'r-Rayyân 2004. 
el-Abderî, Muhammed b. Yûsuf b. Ebî'l-Kâsım b. Yûsuf, et-Tâc ve'l-ikklîl lî Muhtasari Halîl, Beyrût: Dâru'l-Kütübü'l-İlmiyye 2002.

el-İsfehânî Rağıb, el-Müfredât fi garîbi'l-Kur'ân, Çev: Abdülbaki Güneş, Mehmet Yolcu, İstanbul: Çıra Yayınları 2012.

el-Mevs1lî, Abdullah b. Mahmûd b. Mevdûd el-Mevsılî, el-İhtiyâr, Beyrût: Dâru'l-Kütübü'1İlmiyye 2015.

el-Mübârekpûrî, Ebü'l-Ulâ Muhammed Abdurrahmân b. Abdirrahîm, Tuhfetü'l-Ahvezî bi Şerhi Câmii't-Tirmizî, Beyrût: Dâru'l-Fikr 2008.

eş-Şirbînî, Muhammed b. Muhammed el-Hatîb eş-Şirbînî, Muğni'l-Muhtâc ilâ Ma'rifeti Meânielfâzi'l-Minhâc, Dâru'l-Kütübü'l-İlmiyye, Beyrût 2000.

Gündoğdu, Yusuf Bahri, "Mescidlerin Ayrlmaz Bir Unsuru Olarak Eğitim", The Journal of Academic Social Science Studies, S:45 (2016).

Hattâbî, Ebû Süleymân Hamed bin Muhammed b. İbrâhîm el-Hattâbî el-Büstî, Meâlimü's-Sünen, haz. Muhammed Ragıb et-Tabbâh, Halep: Matbaâtü'l-İlmiyye 1932.

Hökelekli, Hayati, "Cinsiyet", TDV İslâm Ansiklopedisi, C:VIII, S:21-24, Türkiye Diyanet Vakfı Yayınları, İstanbul, 1993.

https://kurul.diyanet.gov.tr/Cevap-Ara/108/adetli-ve-lohusa-kadin-camiye-girebilir-mi(09.11.2018).

İbn Hazm El-Endelüsî, el-Muhallâ bi'l-Âsâr, Beyrût: Dâru'l-Kütübi'l-İlmiyye, 2010.

İbn Hâcer El-Askalâni, Ebû'l-Fazl Şihâbüddîn Ahmed bin Alî bin Muhammed, Et-Takrîbü'tTehzîb, Riyâd: Dâru'l-Âsîme tarih yok.

İbn Hacer El-Askalâni, Fethu'l-Bâri Şerhu Sahihi'l-Buhârî, Riyâd: Dâru's-Selâm 2000.

İbn Hibban, Ebû Hâtim Muhammed bin Hibbân bin Ahmed el-Büstî, Kitâbü's-Sikât, Hindistan: Müessesetü Kütübi's-Sekafiyye tarih yok.

İbn Mâce, Ebû Abdillâh Muhammed b. Yezîd Mâce el-Kazvînî, Sünen-i İbn Mâce, Riyâd: Mektebetü'l-Maârif tarih yok.

İbn Manzûr, Ebu'l-Fadl Cemalu'd-din Muhammed b. el-'İzz b. el-Mukerrem el-Ensârî, Lisânü'larab, Beyrût: Dâru Sâdir 2003.

İbn Receb El-Hanbelî, Ebü'l-Ferec Zeynüddîn Abdurrahmân b. Ahmed b. Abdirrahmân Receb el-Bağdâdî ed-Dımaşki, Fethu'l-Bâri alâ Sahîhi'l-Buhârî, Medine: Mektebü'1-Ğurebaü'lEseriyye 1996.

İbn Rüşd, Ebû'l-Velîd Muhammed bin Ahmed bin Muhammed, Bidâyetü'l-Müctehîd ve Nihâyetü'l-Muktesîd, Beyrût: Dâru İbn Hazm 1995.

İbn Salâh, Osmân b. Abdi'r-Rahmân eş-Şeherzûrî, Ulûmu'l-Hadîs, Dâru'l-Fikr, Beyrût, 1986.

Kastallânî, Ebü'l-Abbâs Şihâbüddîn Ahmed b. Muhammed b. Ebî Bekr el-Kastallânî, İrşâdü'sSâri, Misır: Matbaatü'l-Kübrâ h. 1323.

Mergînânî, Alî b. Ebî Bekr b. Abdi'l-Celîl el-Ferğânî, el-Hidâye fì Şerhi' Bidâyetü'l-Mübtedî, Beyrût: Dâru Ahyâ'it-Türâsi'l-Arabî h.1417. 
Mizzî, Ebü'l-Haccâc Cemâlüddîn Yûsuf b. Abdirrahmân b. Yûsuf el-Mizzî, Tehzîbü'l-Kemâl, Beyrût: Müessesetü'l-Risâle 2010.

Müslim, Ebü'l-Hüseyn Müslim b. el-Haccâc b. Müslim el-Kuşeyrî, Sahîhu Müslim, Riyâd: Beytu Efkâri Düveliyye 1998.

Nesâî, Ebû Abdirrahmân Ahmed b. Şuayb b. Alî en-Nesâî, Sünenü'l-Kübrâ, haz.Abdullah bin Abdu'l-Muhsin, (Beyrût: Müessesetü'r-Risâle 2001).

Önkal, Ahmet - BOZKURT Nebi, "Cami ( Din̂̂ ve Sosyokültürel Tarihi )", TDV İslâm Ansiklopedisi, C:VII, S: 46-56, Türkiye Diyanet Vakfı Yayınları, İstanbul, 1993.

Şevkânî, Ebû Abdullah Muhammed b. Ali bin Muhammed el-Havlâni, Neylü'l-Evtâr min Esrâri Münteka'l-Ahbâr, haz. Enver el-Bâz, Misır: Dâru'l-Vefa 2008.

Şeyh Nizam, Fetâvâ-yı Hindiyye, Beyrût: Dâru'l-Fikr 2009.

Tirmîzî, Muhammed b. Îsâ, Câmiu'1-Kebîr, haz. Beşşâr Avvâme, Beyrût: Dâru'1-Ğarabi'1-İslamî 1996.

Yıldırım, Kadri, "İslam Kültüründe Mescidin Eğitim Öğretim Fonksiyonu Üzerine Bir İnceleme", Diyanet İlmi Dergi, Diyanet İşleri Başkanlığı Dini Yayınlar Dairesi Başkanlığı, C: 44, S: 4 (2008).

Yüksek, Ali, "İslam Fıkhına Göre Kadınların Âdet Ve Lohusalık Günlerinde Mescitlere Giriş Sorunu”, Ondokuz İlahiyat Fakültesi Dergisi, S: 41 (2016), s.77- 97.

Zemahşerî, Cârullah Ebî'l-Kâsım Mahmûd bin Ömer, el-Keşşâf, haz. Adil Ahmed Abdi'lMevcûd, Riyâd: Mektebetü'l-Abîkân 1998.

Zeylaî, Ebû Muhammed Cemâlüddîn Abdullāh b. Yûsuf b. Muhammed ez-Zeylaî, Nasbu'r-Râye li Ehâdîsi'l-Hidâye, haz. Muhammed Avvâme, Beyrût: Dâru'l-Kütübi'l- İlmiyye 2010. 